
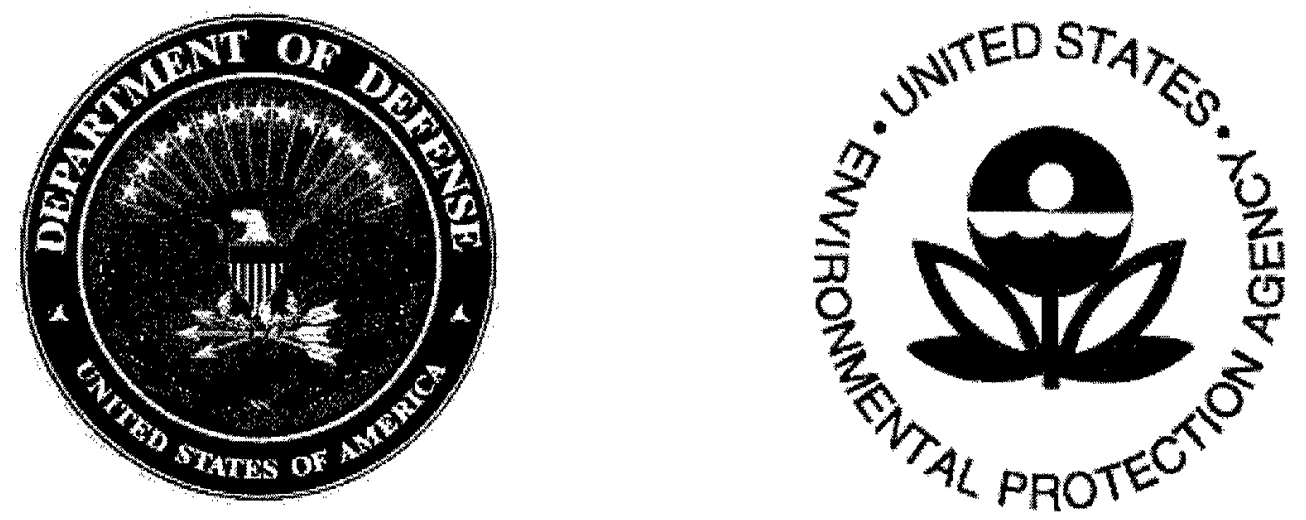

\title{
Lead-Based Paint Guidelines for Disposal Of Department of Defense Residential Real Property - A Field Auide
}

Interim Final

DISTRIBUTION STATEMENT A Distribution Unlic Release

Distribution Unlimited
December 1999

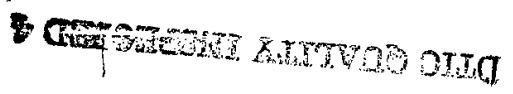
20001211104 


\section{Notice}

The policies set forth in this Field Guide are not intended, nor can they be relied upon, to create any rights enforceable in litigation with the United States. 


\section{Foreword}

One of the federal government's most complex tasks involves ensuring compliance with varied and often conflicting environmental requirements in returning Department of Defense's excess infrastructure to productive use. An area of particular concern, the laws associated with lead-based paint in transferring federal properties, has the potential to delay this effort.

To achieve consistency in the application of the lead-based paint requirements while expediting the availability of property and eliminating possible delays in property transfers, the Department of Defense and United States Environmental Protection Agency, with the assistance of the General Services Administration and the Department of Housing and Urban Development have developed this joint interim final Field Guide. The Field Guide represents a common interpretation of lead-based paint requirements as well as our shared commitment to significantly reduce children's exposures to lead-based paint. Department of Defense and United States Environmental Protection Agency project managers involved in the transfer of residential real property will use the Field Guide as a framework for interpreting the applicable laws and regulations and additional policy requirements imposed by Department of Defense.

The Field Guide requirements are applicable to the transfer of residential real property (housing constructed prior to 1978 and child-occupied facilities), and do not apply to nonresidential structures/property, residential real property not intended for residential occupancy or * reuse as a child-occupied facility, leased property, or active military housing. This Field Guide is being issued as interim final guidance in that requirements relied upon were derived in part from proposed regulations, but should nonetheless be considered the applicable lead-based paint guidance for Department of Defense residential real property transfer until such time as it is amended upon promulgation of the rules.

The protection of children's health is one of our nation's highest priorities. The Field Guide contributes to the advancement of that priority as local communities begin to put excess Department of Defense facilities to productive uses.

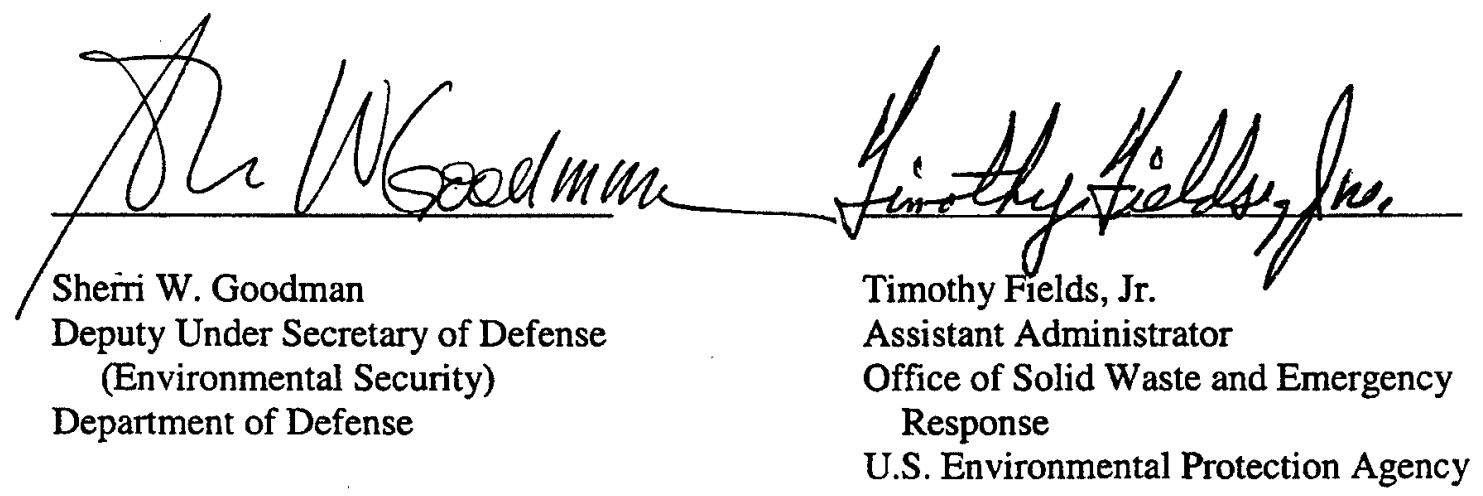




\section{Acknowledgements}

The following Lead-Based Paint Interagency Workgroup members assisted in the development of the Field Guide:

$\begin{array}{ll}\text { Victoria Belfit } & \text { ARMY-CHPPM } \\ \text { Mark Bellis } & \text { ARMY-BRAC } \\ \text { John Bishop } & \text { NAVY-NEHC } \\ \text { Claire Biunno } & \text { AIR FORCE-AFBCA } \\ \text { Richard Butterworth } & \text { GSA } \\ \text { Robert Carr } & \text { USEPA- Region IX } \\ \text { Sandra Cotter } & \text { NAVY-NAVFAC } \\ \text { Diedre Duncan } & \text { ARMY-OGC } \\ \text { Robert Davenport } & \text { ARMY-OGC } \\ \text { Patricia Ferrebee } & \text { DUSD(ES)/CL } \\ \text { John Hamill } & \text { USEPA-Region IX } \\ \text { Camille Hueni } & \text { USEPA-Region VI } \\ \text { Jonathan Jacobson } & \text { USEPA } \\ \text { Gerald Kohns } & \text { NAVY-NAVFAC } \\ \text { Robert LaPoe } & \text { DLA } \\ \text { David Levitt } & \text { HUD } \\ \text { Monica McEaddy } & \text { USEPA } \\ \text { John Michaud } & \text { USEPA } \\ \text { Karen Moran } & \text { DLA } \\ \text { Bryan Nix } & \text { ARMY-ACSIM } \\ \text { Dan Opalski } & \text { USEPA-Region IX } \\ \text { Tamara Paragino } & \text { ARMY-OGC } \\ \text { Colleen Rathbun } & \text { ARMY-AEC } \\ \text { John Shumway } & \text { HUD } \\ \text { Dan Stralka } & \text { USEPA-Region IX } \\ \text { Robert Taylor } & \text { DOD-OGC } \\ \text { Jim Woolford } & \text { USEPA } \\ \text { Renee Wynn } & \text { USEPA } \\ \text { Paul Yaroschak } & \text { NAVY-ASN } \\ \text { Larry Zaragoza } & \text { USEPA } \\ & \end{array}$




\section{Contents}

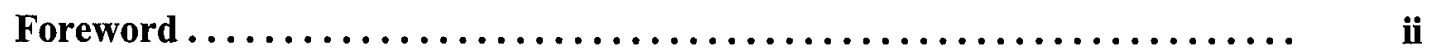

Acknowledgements $\ldots \ldots \ldots \ldots \ldots \ldots \ldots \ldots \ldots \ldots \ldots \ldots \ldots \ldots \ldots$ iii

List of Figures $\ldots \ldots \ldots \ldots \ldots \ldots \ldots \ldots \ldots \ldots \ldots \ldots \ldots \ldots \ldots \ldots \ldots \ldots \ldots$

List of Tables $\ldots \ldots \ldots \ldots \ldots \ldots \ldots \ldots \ldots \ldots \ldots \ldots \ldots \ldots \ldots \ldots \ldots \ldots \ldots \ldots$

Introduction $\ldots \ldots \ldots \ldots \ldots \ldots \ldots \ldots \ldots \ldots \ldots \ldots \ldots \ldots \ldots \ldots \ldots \ldots \ldots \ldots \ldots \ldots$ vii

Chapter 1. Applicable Laws, Regulations, and Guidance ............ 1

Applicable Federal Statutes. . . . . . . . . . . . . . . . . . . . . . 1

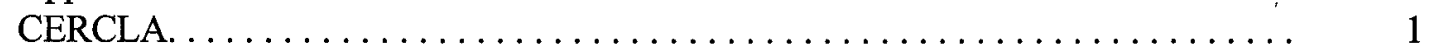

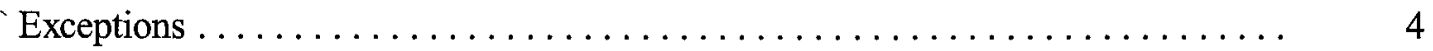

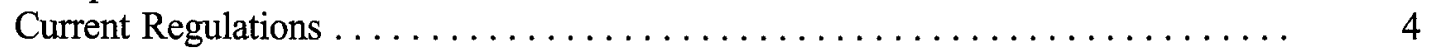

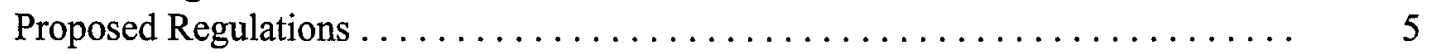

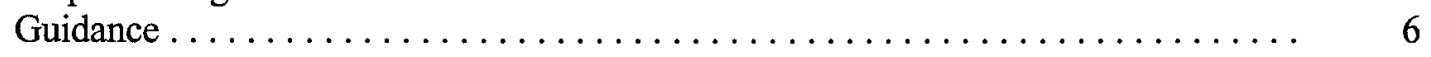

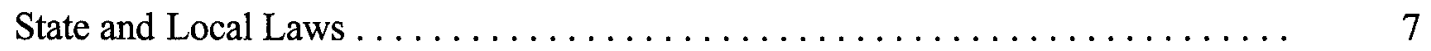

Chapter 2. Lead-Based Paint Evaluation.................... 8

Lead-Based Paint Inspection. . . . . . . . . . . . . . . . . . . . . 10

Risk Assessment . . . . . . . . . . . . . . . . . . . . . . 12

Lead-Based Paint Hazard Criteria $\ldots \ldots \ldots \ldots \ldots \ldots \ldots \ldots \ldots \ldots \ldots \ldots \ldots \ldots \ldots \ldots$

Chapter 3. Lead-Based Paint Control and Hazard Abatement Measures .... 19

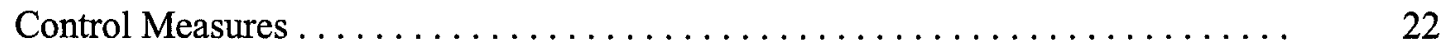

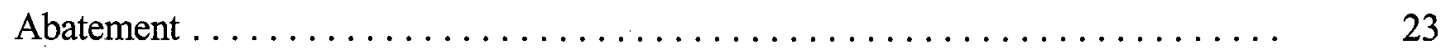

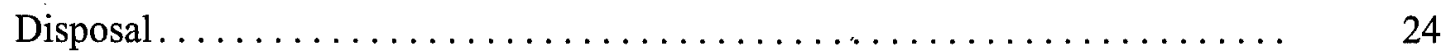

Chapter 4. Property Transfer Process ...................... 25

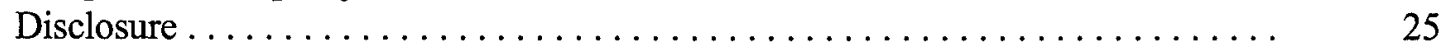

Other Documentation Requirements ..................... 26

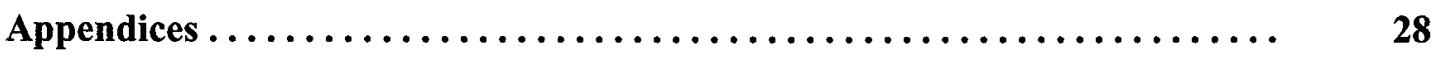

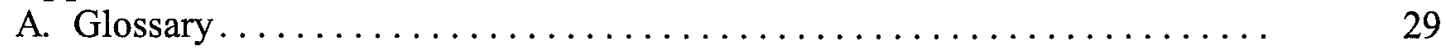

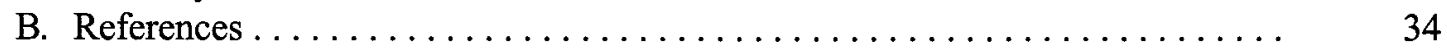

C. Lead-Based Paint Standards and Test Methods .................. 36

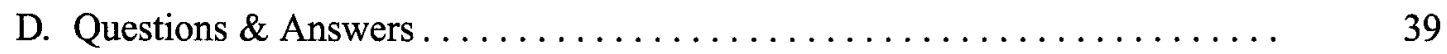

E. DoD Policy and EPA-DoD Agreements .................... 41 


\section{List of Figures}

I-1 Field Guide Overview: Lead-Based Paint Decision Process for Transferring DoD Residential Real Property ............... $\mathrm{x}$

1-1 Applicability of Title X of the Residential Lead-Based Paint Hazard Reduction Act .......................... 3

2-1 The Lead-Based Paint Evaluation Process .................. 9

2-2 The Lead-Based Paint Inspection Process $\ldots \ldots \ldots \ldots \ldots \ldots \ldots \ldots \ldots$

2-3 The Risk Assessment Process. . . . . . . 15

3-1 Control and Hazard Abatement Measures . . . . . . . . . . . . 21 


\section{List of Tables}

2-1 Lead-Based Paint Hazard Recognition ............... 18

3-1 Situations Applicable to Lead-Based Paint Control and Hazard Abatement Measures . . . . . . . . . . . . . . . . . . 20 


\section{Introduction}

Procedures used to address lead-based paint are principally represented by requirements contained in Title X Title X is the Residential Lead-Based Paint Hazard Reduction Act, a portion of the Housing and Community Development Act of 1992 (42 U.S.C. 4851). Title X amends the Lead-Based Paint Poisoning Prevention Act and the Toxic Substances Control Act (42 U.S.C. 2681). Additionally, when this Field Guide refers to "Title X", it includes the implementing regulations under TSCA Section 403 and HUD Section 1012/1013. Although EPA concluded that the release of lead to soil from lead-based paint from structures falls within the CERCLA definition of a hazardous substance release, EPA and DoD agree that for the majority of situations involving target housing, Title $\mathrm{X}$ is sufficiently protective to address the hazards posed by lead-based paint. (See the DoD-EPA Memorandum in Appendix E).

For federally-owned residential real property ${ }^{1}$ subject to disposition ${ }^{2}$, Section 1013 of Title X (42 U.S.C. 4822) requires:

- The inspection, risk assessment, and abatement of lead-based paint hazards in target housing constructed prior to 1960 .

- The inspection and risk assessment for target housing ${ }^{3}$ constructed between 1960 and 1978.

The regulation implementing Section 1013 of Title X 24 CFR 35, was issued as a final rule on 15 September 1999 (64 FR 50140). Subparts of the regulation applicable to federally owned facilities are Subparts A, B, C, and R, and include the following requirements:

- Lead-based paint inspections and risk assessments must be performed for all target housing prior to sale/transfer.

- Risk assessments must be performed within 12 months of the date of transfer, and any abatement required must be conducted no later than 12 months after the completion of the risk assessment.

\footnotetext{
${ }^{1}$ Residential real property is defined as "real property on which there is situated one or more residential dwellings used or occupied, or intended to be used or occupied, in whole or in part, as the home or residence of one or more persons."

${ }^{2}$ Disposition, as the term is used in the Field Guide, means transfer of property, and does not refer to leases, either short or long term, or public/private ventures (PPV).

${ }^{3}$ Target housing, a type of residential real property, is "any housing constructed before 1978, except housing designated exclusively for the elderly or persons with disabilities (unless a child younger than 6 years of age also resides, or is expected to reside, in such housing) or any zero-bedroom dwelling".
} 
- The responsibility for abatement may be assumed by the transferee through the transfer agreement.

- Interim hazard standards for painted components, dusts, and soils are established for use until proposed regulations implementing TSCA Section 403 become effective.

In addition, as a matter of policy, the Field Guide contains a number of requirements that exceed both the current Title $\mathrm{X}$ regulations and the proposed 403 rule. These requirements represent DoD's commitment to exceed what is strictly required by law to ensure that actions taken are protective of children as established by the 1999 DoD "Lead-Based Paint Policy for Disposal of Residential Real Property" (See Appendix E). Field Guide policy requirements include:

- Soil-lead hazards surrounding target housing constructed between 1960 and 1978 will be abated. The purchaser may be required to perform the soil abatement as part of the transfer agreement.

- Potential soil-lead hazards (bare soils with lead concentrations between 400-2000 ppm (excluding children's play areas ${ }^{4}$ )), will be evaluated for the need for abatement, interim controls or no action; the level of action will be determined by the lead-based paint risk assessment.

- Child-occupied facilities (day care centers, preschools, and kindergarten classrooms visited regularly by children under 6 years of age) located on residential real property that will be reused as child-occupied facilities following transfer will be evaluated for leadbased paint hazards. Hazards identified will be abated by the transferee prior to use as a child-occupied facility.

- Target housing that will be demolished and redeveloped as residential real property following transfer will be evaluated by the transferee for soil-lead hazards after demolition of the existing target housing units. Abatement of any soil-lead hazards will be conducted by the transferee prior to occupancy of any newly constructed dwellings.

These requirements expand the application of Title $\mathrm{X}$ requirements to include childoccupied facilities providing an added measure of protection for children. The Field Guide also extends Title $\mathrm{X}$ abatement requirements to soil- lead hazards surrounding housing constructed between 1960 and 1978, ensuring that all soil- lead hazards are abated regardless of the age of the housing.

\footnotetext{
${ }^{4}$ For bare soils in children's play areas, 24 CFR 35, Subpart R defines soil-lead concentrations greater than or equal to $400 \mathrm{ppm}$ as a soil-lead hazard, requiring abatement. (See Chapter 2 and Table 2-1).
} 
The Field Guide is organized into four chapters illustrating the steps to be followed in the evaluation and control of lead-based paint in DoD owned residential real property subject to disposition (Figure I-1):

- Applicable Laws, Regulations, and Guidance

- Lead-Based Paint Evaluation

- Lead-Based Paint Control and Hazard Abatement Measures

- Property Transfer Process.

Decision diagrams have been included for each step of the process. More detailed procedures describing lead-based paint requirements that are provided elsewhere, such as other guidance and regulations, are highlighted in the text and listed in Appendix B for further reference. The appendices also include a list of media sampling and analysis methods, a glossary of commonly used terms, a question and answer section featuring commonly asked questions about disposal of Title $\mathrm{X}$ property, as well as the DoD policy and a letter describing the agreements between EPA and DoD for lead-based paint in DoD residential property transfers.

Note: Throughout this document, terms with definitions provided in the glossary are presented in boldface-italic type. 


\section{Chapter 1}

\section{Applicability of}

\section{Title X}

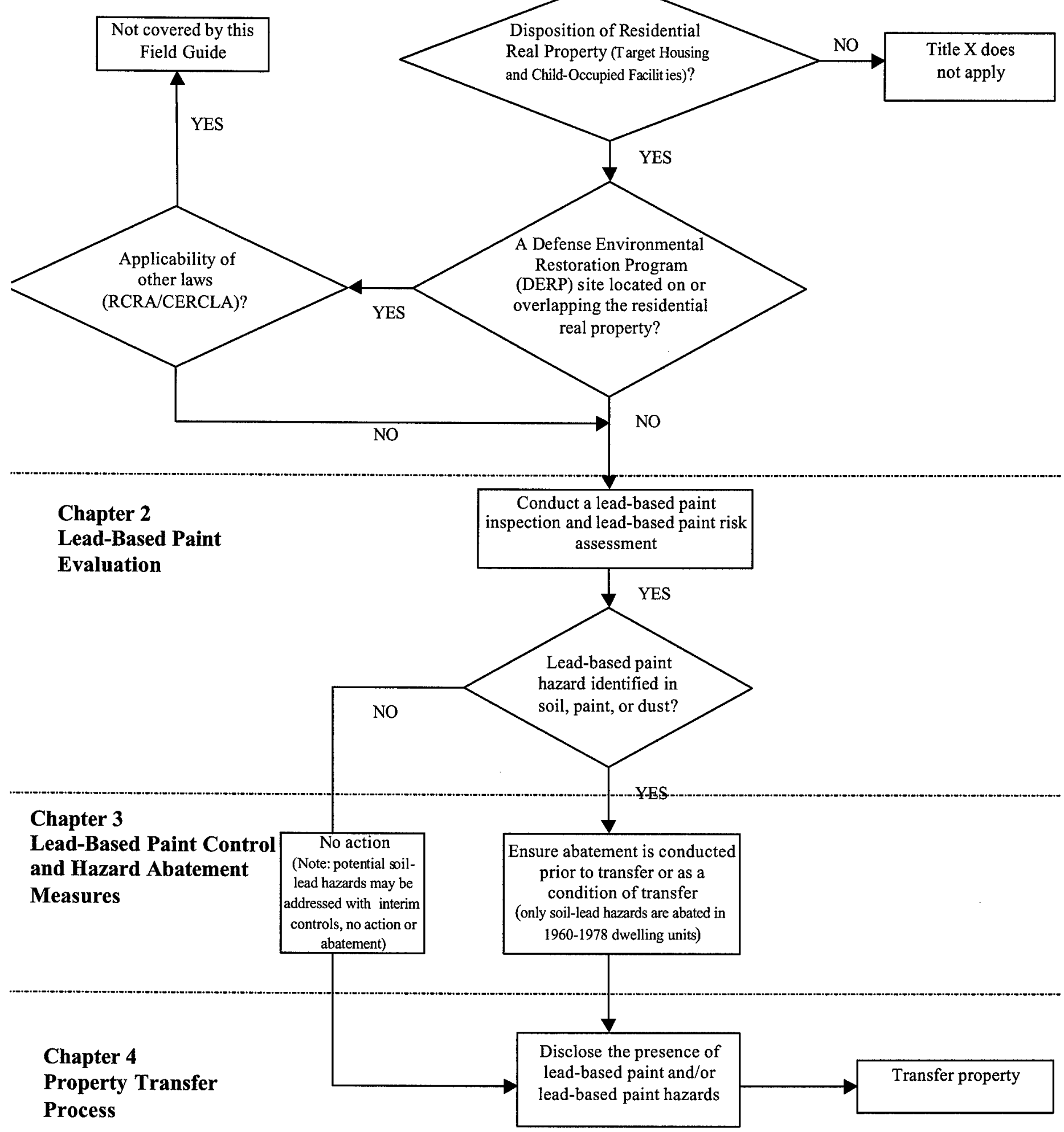

Figure I-1. Field Guide Overview: Lead-Based Paint Decision Process for Transferring DoD Residential Real Property 


\section{Chapter 1:}

\section{Applicable Laws, Regulations, and Guidance}

This section of the Field Guide provides an overview of the applicable regulatory requirements for lead-based paint in DoD residential real property transfers defined by Title $\mathrm{X}$, the Title $\mathrm{X}$ implementing regulations, and other relevant requirements. In addition, this section summarizes the relationship of Title $X$ to other laws, such as CERCLA and the Resource Conservation and Recovery Act (RCRA) as well as other lead-based paint guidance developed by EPA and HUD. Figure 1-1 depicts the general applicability of lead-based paint requirements in DoD residential real property transfer, including the relationship to CERCLA. Note: Actions included in the Field Guide that exceed Title X requirements are provided as a matter of policy.

\section{APPLiCABLe Federal Statutes}

Lead-based paint activities in residential areas are governed by the Residential LeadBased Paint Hazard Reduction Act, commonly known as Title X of the Housing and Community Development Act of 1992, 42 U.S.C. 4822. Title X requires federal departments and agencies to address the threat of lead poisoning from lead-based paint in residential real property. Section 1003 of the Title X statute (42 U.S.C. 4851(a)(6)) states as one of the seven purposes of the legislation that Congress intends "to reduce the threat of childhood lead poisoning in housing owned, assisted, or transferred by the Federal Government." Section 1013 of Title X which amended the Lead-Based Paint Poisoning Prevention Act (42 U.S.C. 4822(a)(3) "requires the inspection and abatement of lead-based paint hazards in all federally owned target housing constructed prior to 1960," as well as "inspection for lead-based paint and lead-based paint hazards in all federally owned target housing constructed between 1960-1977." Sections 1012 and 1013 of Title X require HUD to promulgate regulations for the performance of inspections, risk assessments, interim controls, and abatement of lead-based paint hazards in federally-owned target housing and target housing receiving federal assistance. Section 1018 includes requirements for disclosure of known lead-based paint and lead-based paint hazards before sale or lease of federally owned, federally assisted, and privately owned target housing. Title X also amended the Toxic Substances Control Act (TSCA) (15 U.S.C. 2681), adding provisions for the development of regulations for identifying lead-based paint hazards on residential property (Section 403), including standards for dust and soil. Training and certification for persons involved in lead-based paint activities is authorized under Section 402 (15 U.S.C. 2680). TSCA Section 408 (15 U.S.C. 2688) also contains a waiver of sovereign immunity subjecting the federal government to state laws and regulations.

\section{CERCLA}

DoD has an ongoing program, the Defense Environmental Restoration Program (DERP), to identify, assess, investigate, and cleanup contamination from hazardous substances, pollutants, and wastes resulting from past activities at operational installations and Formerly Used Defense Sites (FUDS) where DoD is the principal responsible party. Although EPA concluded that the release of lead to soil from lead-based paint from structures falls within the CERCLA definition of a hazardous substance release, EPA and DoD agree that for the majority of situations involving target housing, Title $\mathrm{X}$ is sufficiently protective to address the hazards posed by leadbased paint. 
However, lead contamination in soil will be evaluated in accordance with CERCLA/RCRA guidance if a site (the areal extent of contamination) is included in or overlapping a target housing area that is either already being addressed under CERCLA or RCRA as part of the DERP, or has been identified as appropriate for inclusion in the DERP, due to the presence of contamination other than lead-based paint. (See Figure 1-1). Groundwater contamination will not be considered in the determination of CERCLA/RCRA applicability unless the source of groundwater contamination is located in the target housing area. In addition, no further action will be required to address lead in soil from lead-based paint at sites where evaluation and response of soil contamination have been previously completed under either the DERP or Title X unless new regulatory standards that are generally applicable to all parties are promulgated.

When CERCLA or RCRA are being used, the EPA Office of Solid Waste and Emergency Response (OSWER) guidance 9200.4-27P "Clarification to the 1994 Revised Interim Soil Lead Guidance for CERCLA Sites and RCRA Corrective Action Facilities" (August 1998) should be consulted for information regarding investigation and remediation requirements. All other target housing areas should be evaluated in accordance with Title $\mathrm{X}$ and the criteria included in this Field Guide.

Note: DoD requires that structures (water towers, bridges, and communication towers) located in or adjacent to residential areas be included as part of the targeted residential soil sampling as defined by Title X and the HUD Guidelines. See Chapter 2 of this Field Guide. 


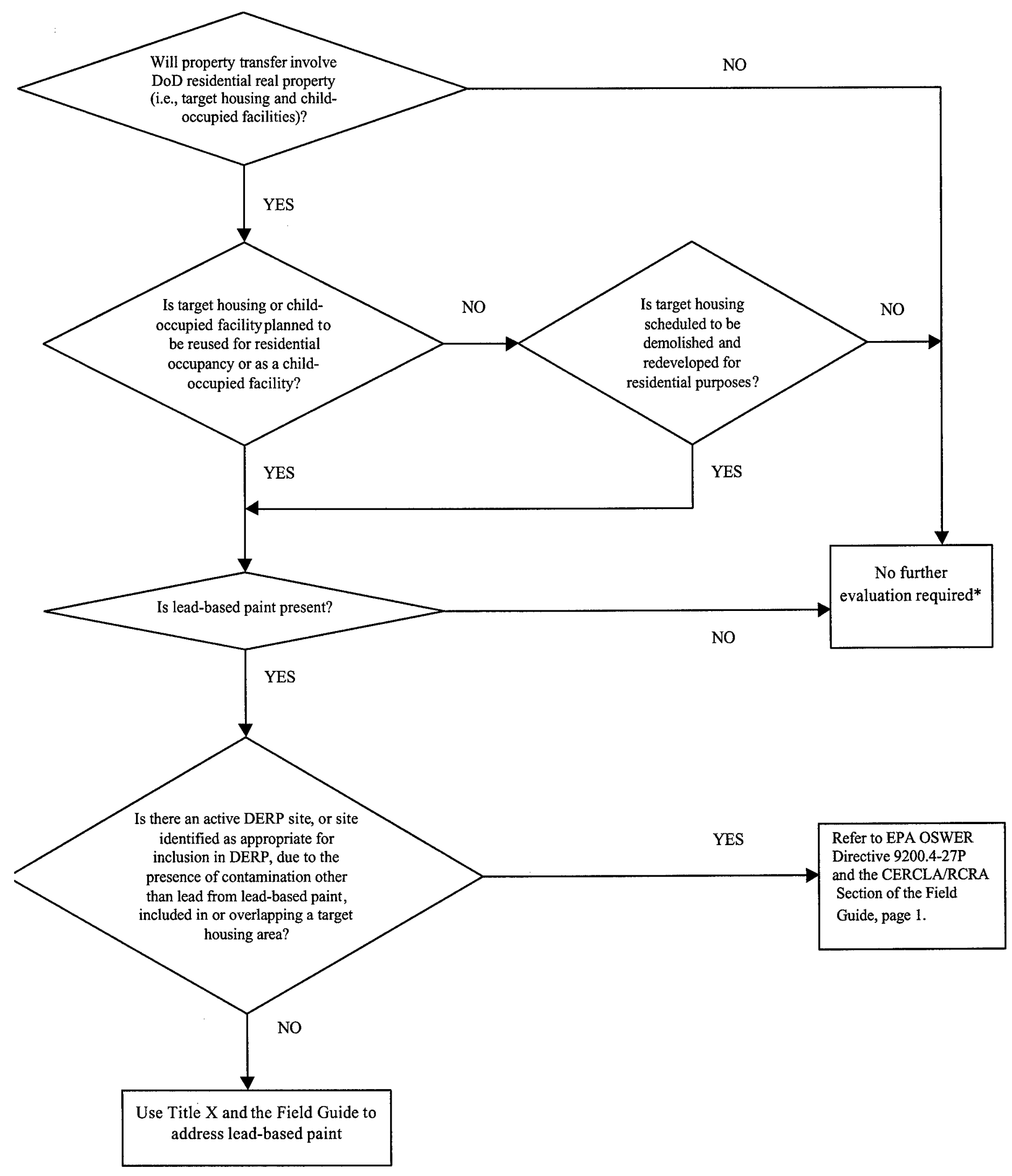

Figure 1-1. Applicability of Title $X$ of the Residential Lead-Based Paint Hazard Reduction Act

*This neither exempts such areas from the DERP with respect to the presence of contamination other than lead

from lead-based paint, nor creates requirements for such areas under the DERP. 


\section{EXCEPTIONS}

The Field Guide lead-based paint requirements are only applicable to circumstances involving the transfer of DoD residential real property. Affected residential real property includes: child-occupied facilities located on residential real property, target housing, and target housing planned to be demolished following transfer and redeveloped for residential use. The requirements contained in the Field Guide do not apply to the following types of property:

- Property not scheduled to be transferred.

- Structures not contained within the definition of residential real property. Residential real property does not include schools, shopping malls, churches, barracks, or other nonresidential structures.

- Residential dwellings constructed after 1 January 1978.

- Housing designated exclusively for the elderly or persons with disabilities (unless a child younger than 6 years of age also resides, or is expected to reside in such housing) or any zero-bedroom dwelling (such as barracks).

- Leased property or other property not subject to disposition

- Residential real property not intended for residential occupancy or use as a childoccupied facility following transfer.

- Residential real property included in transfer agreements executed prior to the effective date of the DoD Lead-Based Paint Policy for Disposal of Residential Real Property. Services must still meet any promulgated regulatory requirements applicable to the disposition of real property in effect on the date of the disposition of the property.

\section{CURRENT Regulations}

Current regulations governing lead-based paint activities include the following:

- 24 CFR Part 35, Subpart A (HUD), and 40 CFR Part 745, Subpart F (EPA), "Disclosure of Known Lead-Based Paint and Lead-Based Paint Hazards upon Sale or Lease of Residential Property". Under Section 1018 of Title X EPA and HUD jointly issued disclosure requirements. Sellers and lessors of target housing must disclose the presence of known lead-based paint and/or lead-based paint hazards in the housing, including providing any available records or reports, and provide a lead hazard information pamphlet. They are also required to attach to the sales contract or lease a form that contains, in addition to disclosure, a lead warning statement and signature lines. Sellers must also provide buyers with a 10-day opportunity to conduct a lead-based paint inspection or risk assessment.

- 24 CFR 35 et al., "Requirements for Notification, Evaluation, and Reduction of LeadBased Paint Hazards in Federally Owned Residential Property and Housing Receiving Federal Assistance," (64 FR 50140), effective 15 September 2000, implements sections 1012 and 1013 of Title X Subpart B includes general requirements applicable to all subparts. Subpart C establishes procedures for the disposition of federally owned residential property. Subpart $\mathrm{R}$ provides methods and standards to be used for evaluation and abatement activities conducted under Subparts B, C, D, and F through Subpart M, and includes "interim hazard standards" for paint, dust, and soil to be used until standards contained in the proposed TSCA 403 regulation are effective. 
- 40 CFR Part 745, Subpart E, "Residential Property Renovation" effective June 1, 1999, requires individuals paid to perform renovations on target housing to provide a lead hazard information pamphlet to the owner/occupant prior to commencing any renovation activities, as required under TSCA Section 406.

- 40 CFR Part 745, Subpart L, “Lead-Based Paint Activities" effective March 1, 2000 (64 FR 42849), includes both training and certification requirements for persons involved in lead-based paint activities in target housing, as well as work practice standards for conducting lead-based paint inspections, risk assessments, and abatement activities as required by Section 402 of TSCA Subpart $L$ also references the procedures contained in the HUD Guidelines and the TSCA guidance.

- 40 CFR Part 745, Subpart Q, "State and Indian Tribal Programs". The regulation establishes requirements for State or Tribal programs under Section 404 of TSCA, for authorization to administer and enforce regulations developed under TSCA Section 402.

- 29 CFR \$1926.62, Occupational Safety and Health Administration (OSHA) Regulations, "Lead Exposure in Construction" Section 1926.62 applies to all construction activities in which employees might be exposed to lead and all related construction activities currently excluded from the general industry standard for lead (29 CFR \$1910.1025).

- 40 CFR Part 261, Subpart B, "Criteria for Identifying the Characteristics of Hazardous Waste and for Listing Hazardous Waste." This regulation defines chemical testing requirements used to characterize wastes for disposal under the Resource Conservation and Recovery Act (RCRA).

\section{Proposed Regulations}

Regulations implementing Title $\mathrm{X}$ that have been proposed but are not yet final include:

- The proposed TSCA regulation "Identification of Dangerous Levels of Lead"

(63 FR 30302) establishes lead-based paint hazard standards under section 403 of TSCA for painted surfaces, dusts, and soils.

- Proposed TSCA regulation, "Management and Disposal of Lead-Based Paint Debris", (63 FR 70189) and the proposed RCRA regulation, "Temporary Suspension of Toxicity Characteristic Rule for Specified Lead-Based Paint Debris" (63 FR 70233) . Currently, lead-based paint wastes which fail testing required under the Toxicity Characteristic (TC) Rule (40 CFR 261.24) must be disposed of as hazardous waste. The proposed RCRA regulation would suspend the RCRA testing and disposal requirements for certain types of lead-based paint debris generated during abatements, deleading projects at public or commercial buildings, and renovation or remodeling and demolition activities at target housing, public buildings or commercial buildings. Instead, debris such as lead-based painted architectural component debris and lead-based paint demolition debris would be managed as non-hazardous solid waste in accordance with the proposed TSCA disposal requirements. 
When the regulations are promulgated, the work practices, hazard standards, and disposal requirements they contain will become requirements. Any changes in the final rules will be incorporated into subsequent versions of this Field Guide. In the interim, hazard criteria included in this Field Guide incorporate the requirements of 24 CFR 35 and the language and intent of the proposed Section 403 regulation Field Guide waste management requirements reference only the current RCRA regulations.

\section{GUIDANCE} activities:

There are two primary guidance documents currently recommended for lead-based paint

- HUD Guidelines for the Evaluation and Control of Lead-Based Paint Hazards in Housing, June 1995 (including the September 1997 revision of Chapter 7: Lead-Based Paint Inspection).

- EPA Interim Guidance on the Identification of Lead-Based Paint Hazards, 60 FR 47248, September 11, 1995.

The HUD Guidelines provide detailed procedures to be used for performing inspections, risk assessments, interim controls, and abatement, and are referenced throughout the Field Guide. The HUD Guidelines, Chapter 5, "Risk Assessment", and Chapter 15, "Clearance", are scheduled to be revised. The HUD Guidelines can be downloaded from the HUD Office Lead Hazard Control Internet home page at http://www.hud.gov/lea/learules.html. EPA is in the process of developing guidance to implement the proposed TSCA 403 rule, which will eventually replace the 1995 interim guidance. The TSCA guidance can be obtained from the EPA Lead Programs home page at http://www.epa.gov/opptintr/lead/index.html. Army, Navy, and Air Force are also developing guidance to supplement Field Guide requirements consistent with DoD lead-based paint policy.

\section{STATE AND LOCAL LAWS}

TSCA (15 U.S.C. 2688) contains a waiver of sovereign immunity for state and local laws relating to lead-based paint and lead-based paint activities. Most states now have authorized programs under 40 CFR Part 745, Subpart Q, defining training and certification requirements for inspectors, risk assessors, and abatement contractors involved in lead-based paint activities.

Authorized programs may include standards for lead-based paint that may be more stringent than current federal regulations, the proposed TSCA 403 rule standards, or Field Guide requirements. States may also have specific testing and disposal requirements for lead-based paint waste and debris generated during abatement and demolition activities. Lead-based paint evaluation and abatement activities and disposal of lead-based paint debris must comply with promulgated state requirements.

Local interest from communities, Land Reuse Authority, the BRAC Cleanup Teams, as well as prospective purchasers may also have some bearing on decisions made by DoD on property transfer issues, such as lead-based paint. In addition, where lead-based paint is associated with historic residential properties, state historic preservation offices should also be consulted regarding acceptable abatement requirements for planned restoration activities of historic properties. 


\section{Chapter 2: \\ Lead-Based Paint Evaluation}

The term evaluation means an inspection and a risk assessment and can also include a lead-hazard screen, paint testing, or a combination of these to determine the presence of leadbased paint hazards or lead-based paint. The lead-based paint inspection is used to establish the presence or absence of lead-based paint on interior and exterior surfaces. The risk assessment is conducted to assess whether painted surfaces, dusts, and soils represent lead-based paint hazards and recommend options for hazard abatement.

24 CFR 35, Subpart C requires a lead-based paint inspection, risk assessment, and abatement of lead-based paint hazards in federally owned target housing constructed prior to 1960 and an inspection for lead-based paint and risk assessment for lead-based paint hazards in federally owned target housing constructed between 1960 and 1977. Both the lead-based paint inspection and risk assessment are required to be performed prior to transfer, with the risk assessment conducted no more than 12 months prior to transfer.

DoD policy requires that child-occupied facilities located on residential real property be evaluated in the same manner as target housing. Target housing that will be demolished and redeveloped for residential use following transfer does not require either an inspection or risk assessment, but DoD policy requires soils be evaluated by the transferee after demolition and prior to occupancy of any newly constructed units.

The lead-based paint inspection will usually precede the risk assessment. The results of the inspection are used in the risk assessment in the evaluation of lead-based paint hazards. However, military services may elect to combine the lead-based paint inspection and risk assessment into one evaluation. As shown in Figure 2-1, if the lead-based paint inspection indicates the absence of lead-based paint on the exterior and interior surfaces of the property, a risk assessment is not required, and no further action is necessary. Accordingly, if lead-based paint hazards are not identified in the risk assessment, no further action other than disclosure is required. The presence of lead-based paint should be established prior to conducting the risk assessment.

EPA's 40 CFR Part 745, Subpart L, "Work Practice Standards for Conducting LeadBased Paint Activities," provides minimum requirements for conducting lead-based paint inspections and risk assessments, and references detailed requirements contained in the 1995

EPA TSCA guidance and the HUD Guidelines. All lead-based paint inspections and risk assessments should be conducted by a certified inspector or risk assessor, respectively, in accordance with TSCA Section 402, state, and local requirements. The certified individual and the responsible military Service must retain copies of the inspection and risk assessment reports for a minimum of three years. As discussed in Chapter 4, the results of lead-based paint inspections and risk assessments are disclosed to the transferee in the transfer agreement. 


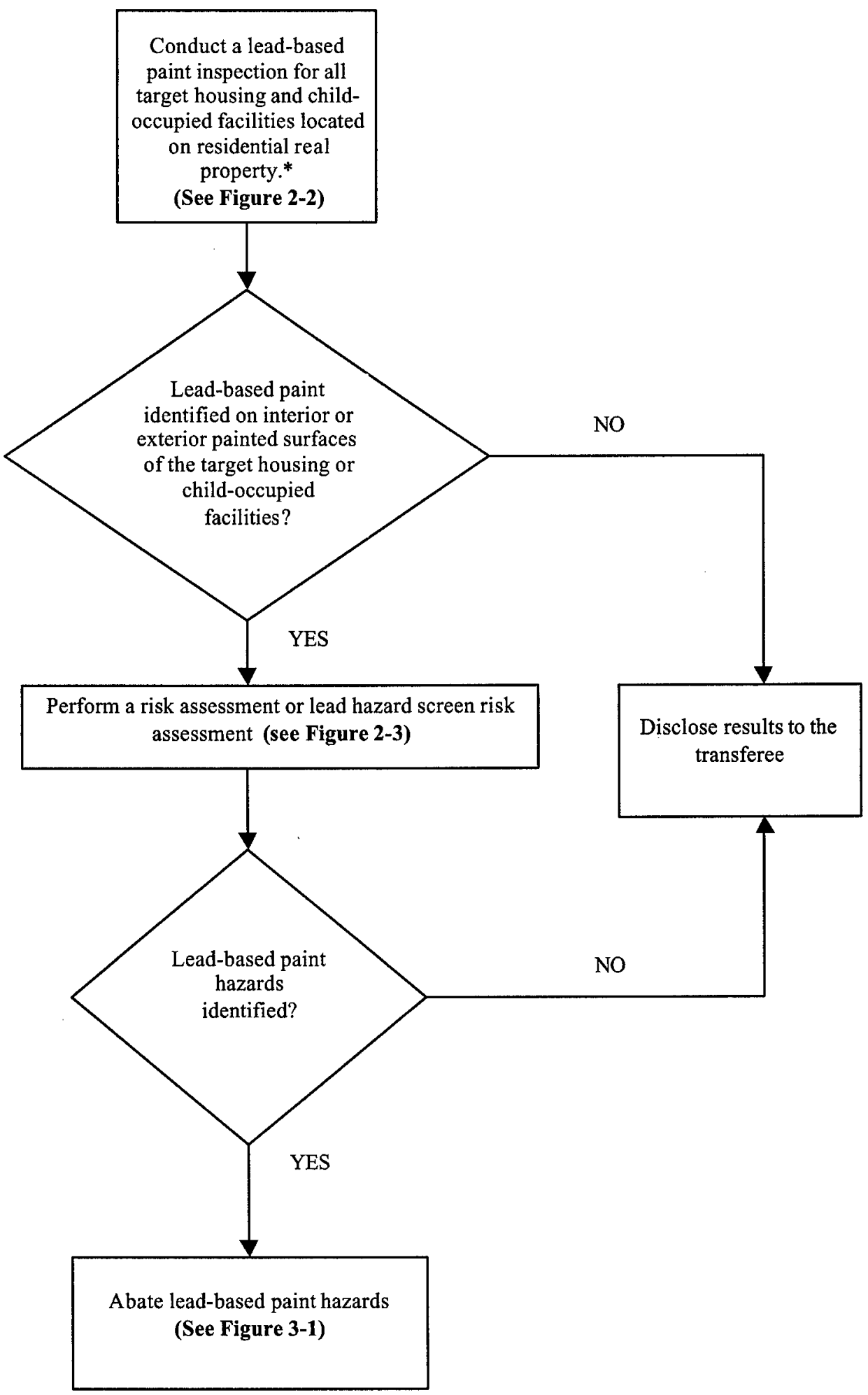

Figure 2-1. The Lead-Based Paint Evaluation Process

*A lead-based paint inspection and risk assessment are not required to be performed for housing that will be demolished. However, soils are required to be evaluated and abated by the transferee following demolition and prior to occupancy of any newly constructed dwelling units. 


\section{Lead-BASed Paint InsPection}

A [lead-based paint] inspection is a surface-by-surface investigation to determine the presence of lead-based paint and the provision of a report explaining the results of the investigation. $24 \mathrm{CFR} 35$, Subpart $\mathrm{C}$ and DoD policy requires that a lead-based paint inspection be performed for all target housing and child-occupied facilities located on residential real property. 40 CFR Part 745, Subpart L requires that lead-based paint inspections be performed by a certified inspector and in accordance with the procedures contained in 40 CFR 745.227 and Chapter 7 of the HUD Guidelines, (revised September 1997).

An inspection is used to inventory the painted surfaces of the interior and exterior of a dwelling unit. The inventory involves testing of all of the "testing combinations," which are distinct combinations of building components, substrates, and locations (room, hallway, exterior, etc.). (Because of their large area, at least four walls are tested in each room or room equivalent.) The inspector is responsible for characterizing the distinct components for which testing may be required. Certain adjacent building components that are not likely to have different painting histories can be grouped together in a single testing combination (HUD Guidelines, Chapter 7, rev. 1997, http://www.hud.gov/lea/chap7 2.pdf ). For multi-family housing with similarly constructed dwelling units, the inspector will select units, common areas, and exterior areas for testing to represent conditions in all units and common areas, in accordance with the sampling strategy provided in the HUD Guidelines, Chapter 7 (see, especially, Table 7.3). Components replaced after 1977 or known not to contain lead-based paint do not require inspection.

Portable $\mathrm{x}$-ray fluorescence (XRF) analyzers combined with laboratory analysis of paint samples are used to determine the presence of lead-based paint. The XRF is the most commonly used inspection method because it provides immediate results, is economical to use, and sampling does not disturb the painted surface. The XRF must be operated in accordance with the instrument's performance characteristic sheet (PCS), the manufacturer's recommendations, and the HUD Guidelines, Chapter 7. The XRF cannot be used on deteriorated or irregular surfaces. Paint chip sampling must be used when paint on deteriorated or irregular surfaces must be tested, and as confirmation for inconclusive XRF results. A paint chip sample includes all layers of paint on a tested component. Paint chip samples are required to be analyzed at laboratories recognized by EPA under the National Lead Laboratory Accreditation Program (NLLAP) as being capable of performing analyses for lead in paint, dust, and/or soil samples, as applicable to the sample being analyzed. (40 CFR 745.227(f)(2) and the HUD Guidelines, Chapter 7).

If lead-based paint is identified, a lead-based paint risk assessment should be conducted consistent with the recommendations and requirements provided in the next section and Chapter 5 of the HUD Guidelines. If no lead-based paint is detected, no further action is required (24 CFR 35.115 (a)(4)). The inspector should document all findings in an inspection report, as described in Chapter 7 of the HUD Guidelines. See Figure 2-2 for an overview of the lead-based paint inspection process. 


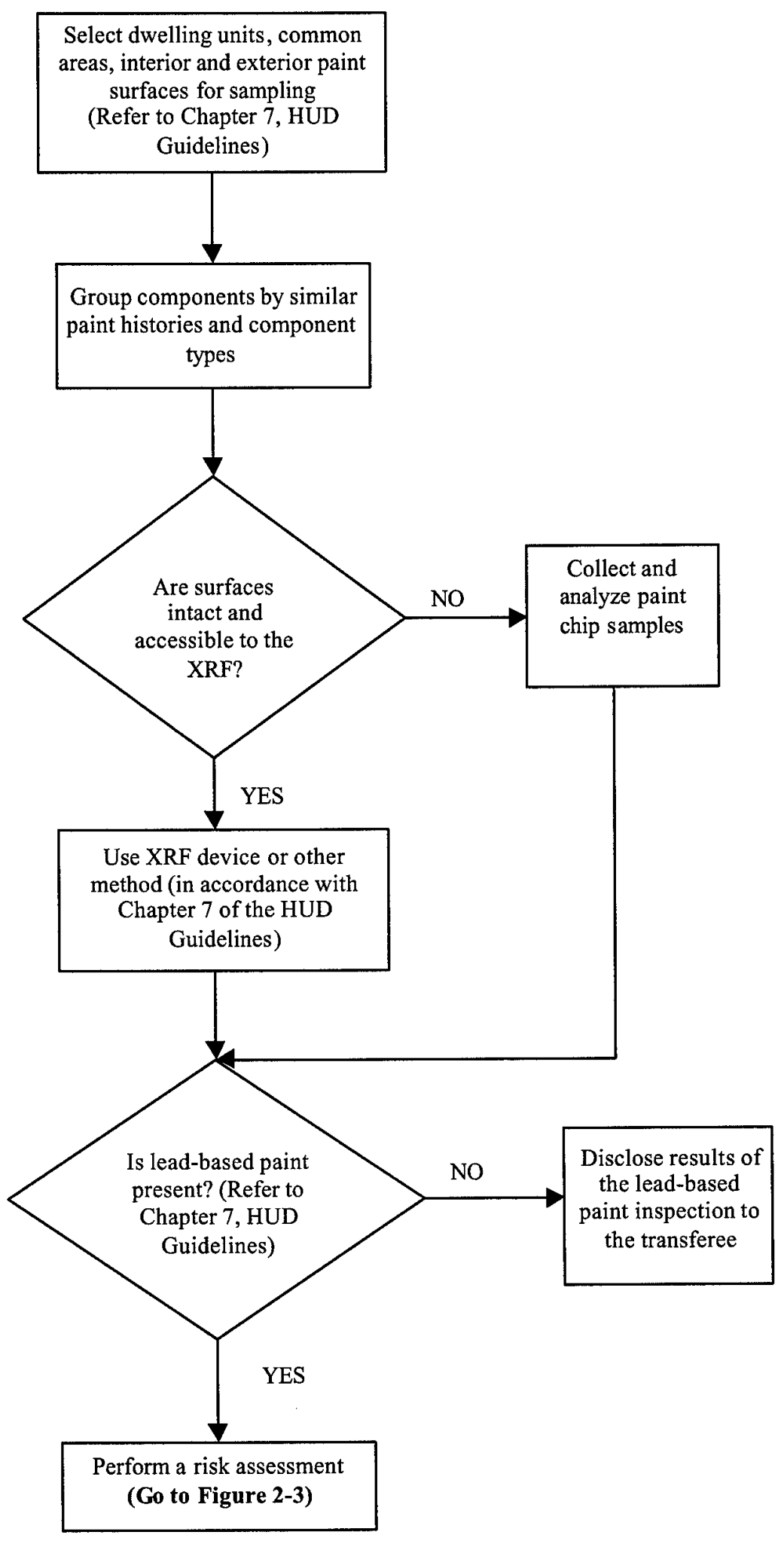

Figure 2-2. The Lead-Based Paint Inspection Process 


\section{RISK ASSESSMENT}

A risk assessment is an on-site investigation to determine and report the existence, nature, severity, and location of lead-based paint hazards in residential dwellings [on painted surfaces in the interior and on the exterior of the dwelling, in interior dusts, and in soils on the residential property]. (HUD Guidelines, Chapter 5, http://www.hud.gov/lea/leach5.pdf). 24 CFR $35.165(\mathrm{~b})(1)$, requires that a "risk assessment must be no more than 12 months old to be considered current", in which case the risk assessment must be conducted no more than 12 months prior to disposition The risk assessment can be a separate study performed after a leadbased paint inspection, a lead hazard screen assessment, or may be combined with the leadbased paint inspection. An EPA certified risk assessor or an individual certified by an authorized state program must conduct the risk assessment.

A lead hazard screen risk assessment may be appropriate if, based on-site history and other features; the residential dwelling is unlikely to contain lead-based paint hazards. The lead hazard screen usually involves limited paint and dust sampling but can also include soil sampling. If no lead-based paint hazards are identified during the lead hazard screen risk assessment, no further action is required. However, if lead-based paint hazards are found or are suspected to be present, a full risk assessment should be performed to define specific surfaces/media requiring abatement. The sampling results from the lead hazard screen may be used to supplement sampling required for the risk assessment. The evaluation and reporting process for the lead hazard screen risk assessment is similar to the risk assessment requirements discussed below. Note: the value of the dust-lead hazard standard used in the lead hazard screen is less than the standard used in the risk assessment. (See the glossary definition and Table 2-1.) A risk assessment consists of the following general steps:

- An evaluation of the history and background of the target housing or child-occupied facility, including a review of available information on the age and history of the structures, occupancy by children under the age of six, and the physical characteristics of the building.

- A visual inspection to determine the presence, location, and extent of deteriorated paint and other lead-based paint hazards. The visual inspection also includes an assessment of probable use patterns that could result in exposure to lead-based paint.

- Sampling of paint, dust, and soil media.

- Testing of each deteriorated painted surface with a distinct painting history that has been identified as containing lead-based paint. The lead-based paint inspection should be consulted in determining the need for any additional painted surface samples. Either the XRF or paint chip sampling may be used to evaluate painted surfaces. All paint chip, dust, and soil samples must be analyzed by laboratories recognized by EPA through the NLLAP as described in 40 CFR 745.227(f)(2).

- Collection of dust wipe samples, either composite or single surface samples, from interior windowsills and floors in all living areas where young children are most likely to come into contact with dust. Dust wipe samples should be collected from 
window sills and floors in all living areas where one or more children, age 6 and under, are most likely to come into contact with dust. For multi-family property dwellings and child-occupied facilities dust samples should also be collected from windows and floors in common areas. More detail regarding dust-sampling protocols can be found in the HUD Guidelines, Chapter 5, and 40 CFR §745.227.

- Collection of composite soil samples from the first $1 / 2$ inch of soil from the dripline/foundation and the midyard areas where bare soil is present. Composite sampling procedures are defined in the HUD Guidelines, Chapter 5. Sampling requirements include:

- Two composite samples collected from bare soil areas in the midyard and dripline respectively. Each composite sample is made up of two or more subsamples but not to exceed 10 subsamples.

- Separate composite samples collected from bare soils in children's play areas.

The arithmetic mean, or the average of the composite samples, is used to define a yardwide average of soil lead concentrations. If the arithmetic mean of the composite samples is equal to or exceeds the hazard standard of 2,000 ppm in bare soils (bare soil areas must exceed 9 square feet) or $400 \mathrm{ppm}$ in children's play areas, additional sampling may be required to define the extent of soil requiring abatement. The results of the midyard or dripline composite sampling may be used to target areas of bare soils for additional sampling. For target housing scheduled to be demolished and redeveloped for residential use after transfer, the transferee will be responsible for evaluating and abating any soil-lead hazards. The transfer agreement should specify that soil sampling be conducted after demolition and removal of demolition debris and prior to occupancy of any newly constructed dwelling units in a manner consistent with Title $\mathrm{X}$ and the HUD guidelines.

- Evaluation of all sampling data, background information, findings from the visual assessment, and management and maintenance information against the lead-based paint hazard criteria in Table 2-1, to determine the presence or likelihood of exposure by children to lead-based paint hazards in dusts, soils, painted surfaces and potential hazards in soils (soil lead concentrations between 400 and 2,000 ppm (excluding children's play areas)).

- Preparation of a risk assessment report documenting all sampling data, related lead-based paint hazards, and recommended options for control and/or hazard abatement.

The risk assessment may use several different sampling strategies for multifamily dwellings, including targeted, worst-case, or random sampling of dwelling units for housing with five or more dwelling units, as defined in Chapter 5 of the HUD Guidelines. The facility should select a sampling strategy on the basis of the desired degree of confidence, economic factors, and the availability of historical construction and maintenance records, in accordance with the HUD Guidelines or other documented EPA methodologies. 
If the condition of painted surfaces and concentrations of lead in paint and other media do not exceed the hazard criteria as either a lead-based paint hazard or a potential hazard, as described in Table 2-1, then no further action is required. Identified lead-based paint hazards must be abated. Potential soil-lead hazards may be addressed through interim controls, no action, or abatement, as determined by the criteria discussed on page 17 and Table 2-1. Figure 23 provides an outline of the risk assessment process. 


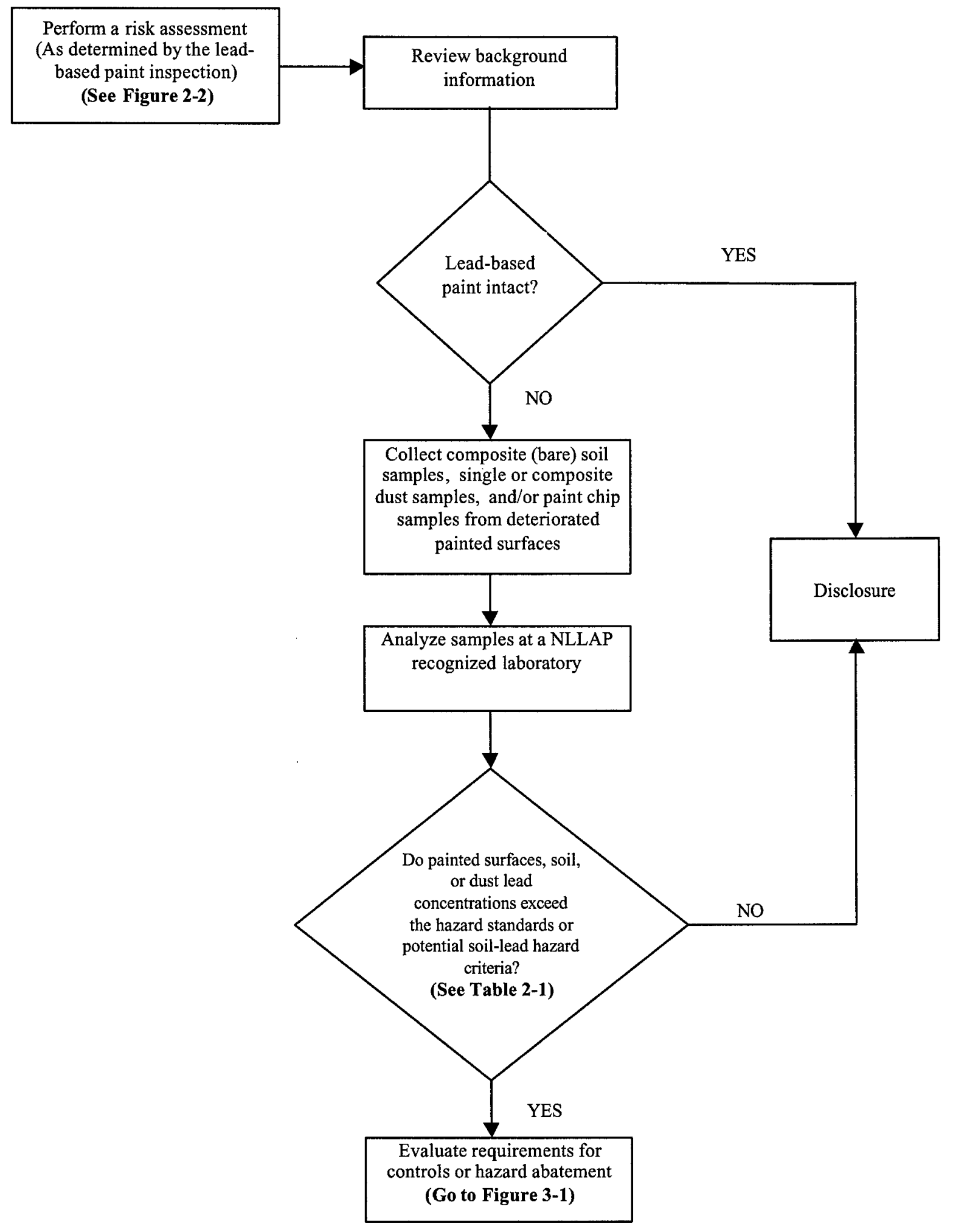

Figure 2-3. The Risk Assessment Process 


\section{Lead-Based Paint Hazard Criteria}

Lead-based paint hazard criteria, as defined by 24 CFR 35, Subpart R and DoD policy, for all three sources; painted surfaces (including accessible, friction, and impact surfaces), dusts, and soils, as they apply to target housing and child-occupied facilities, are summarized in the following paragraphs and Table 2-1.

Deteriorated Painted Surfaces. Painted surfaces must meet two conditions to be considered lead-based paint hazards: the paint film must contain lead-based paint and the surface must be deteriorated. Intact surfaces containing lead-based paint are not considered lead-based paint hazards and thus do not require abatement. Lead-based painted surfaces with deteriorated paint, regardless of the extent of the deterioration, must be abated.

Chewable (Accessible), Friction, and Impact Surfaces. Accessible, friction, and impact surfaces are a special class of painted surfaces with slightly different hazard assessment criteria. A friction surface is an interior or exterior surface that is subject to abrasion or friction, including certain window, floor, and stair surfaces. An impact surface is an interior or exterior surface that is subject to damage by repeated impacts from related building components, for example, certain parts of doorframes. A chewable or accessible surface is an interior or exterior surface painted with lead-based paint that is accessible to a young child to mouth or chew. Friction surfaces are considered a lead-based paint hazard if all of the following three criteria are satisfied: the surface contains lead-based paint, there is a dust lead hazard present on the nearest horizontal surface underneath the friction surface, and the surface is abraded. An impact surface is a lead-based paint hazard if there is lead-based paint present, paint on the impact surface is deteriorated or damaged, and the damaged paint is caused by impact with a related building component. Lead-based paint hazards identified on friction or impact surfaces must be abated. An accessible surface is a lead-based paint hazard if the painted surface shows evidence of teeth marks. If an accessible surface is a lead-based paint hazard, only the component bearing that surface should be abated. If no teeth marks are evident, the surface is considered to be intact and is not a lead-based paint hazard.

Dusts. Lead-based paint hazard criteria for dusts or dust-lead hazards are defined for carpeted and uncarpeted floors and interior window sills on the basis of either single surface or composite dust samples. If the floor and window sill composite or single surface dust wipe sample concentrations from any given room or common area exceeds $40 \mu \mathrm{g} / \mathrm{ft}^{2}$ on uncarpeted and carpeted floors or $250 \mu \mathrm{g} / \mathrm{ft}^{2}$ on interior window sills, dusts in that room or common area represent a lead-based paint hazard, and the source of the dust should be identified and controlled.

Soils.

- Soil Lead Hazard. A soil-lead hazard is a concentration of lead in soil greater than or equal to $400 \mathrm{ppm}$ in bare soils in children's play areas, or greater than or equal to $2000 \mathrm{ppm}$ in bare soil areas greater than 9 square feet based on a yardwide arithmetic mean of composite samples. Note: Hazard criteria for children's play areas are not applicable to either metal structures, described on page 2, or dwelling units that will be demolished following transfer and redeveloped for residential use. 
- Potential Soil-Lead Hazard: DoD defines a potential soil-lead hazard as concentrations of lead in bare soil areas greater than 9 square feet surrounding a dwelling unit that are greater than or equal to $400 \mathrm{ppm}$ and less than $2000 \mathrm{ppm}$. As a matter of policy, services may undertake measures to address potential soil lead hazards such as abatement or interim controls, or determine that no action is appropriate based on the lead-based paint inspection and risk assessment. In evaluating each of these alternatives the risk assessor should consider the relative proximity of children's play areas, the potential for dust generation and the areal extent of bare soil available for exposure, state and local requirements, as well as the feasibility of any potential control options. Note: Potential soil-lead hazards do not include children's play areas and are not defined for metal structures. 


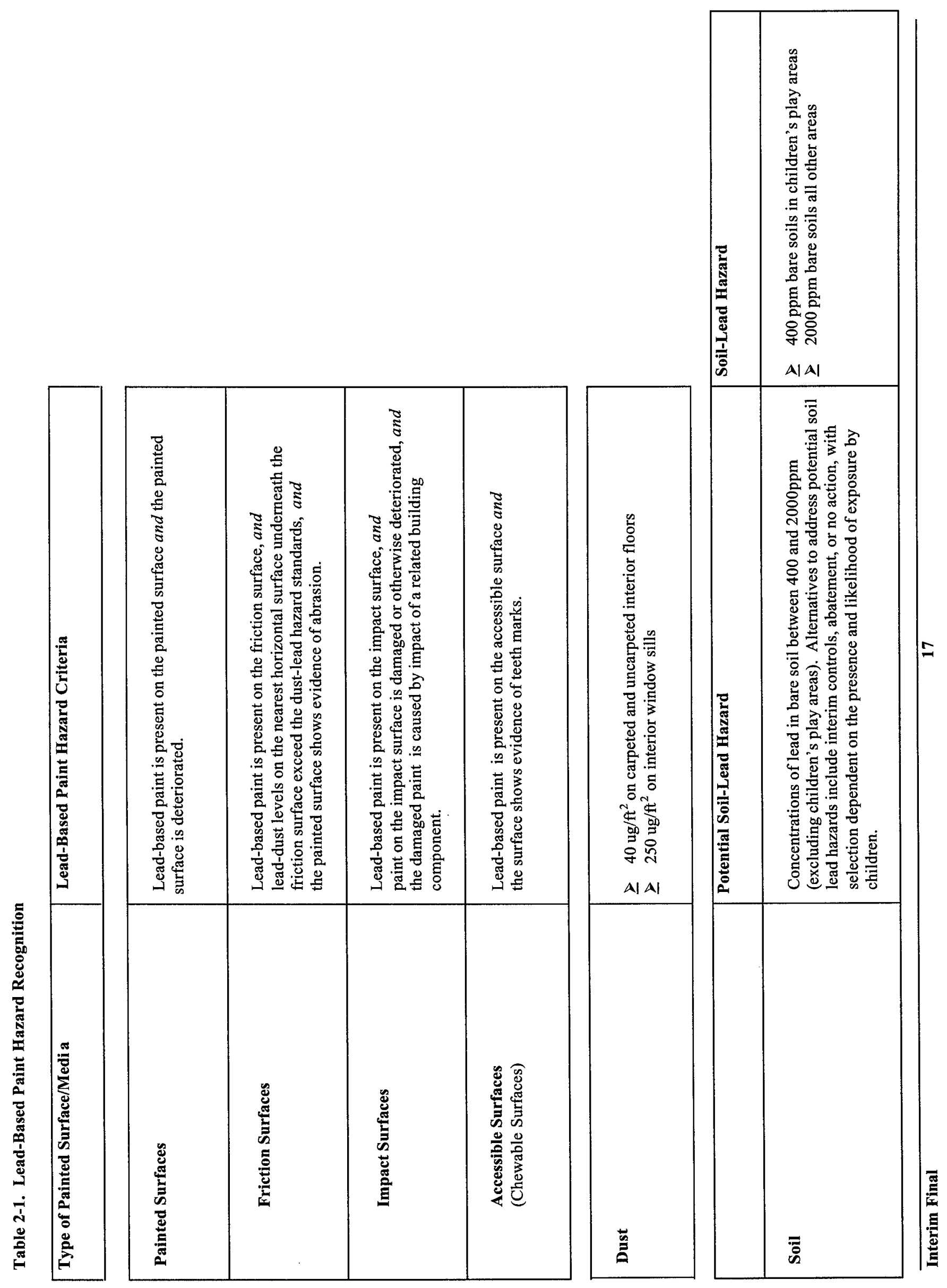




\section{Chapter 3: \\ Lead-Based Paint Control and Hazard Abatement Measures}

Title $\mathrm{X}$ requirements for control or abatement of lead-based paint hazards differ depending on the age of the housing. 24 CFR 35, Subpart C requires abatement of lead-based paint hazards identified in target housing constructed before 1960. For target housing constructed between 1960 and 1977, the regulation requires that the presence of any known leadbased paint and/or lead-based paint hazards be disclosed to the transferee of the property, but does not require abatement or control of lead-based paint and/or lead-based hazards. The abatement must be conducted no later than 12 months after the risk assessment is completed and may be implemented prior to disposition of the property or may be made a condition of the property transfer. Interim controls may not be used to address lead-based paint hazards required to be abated under 24 CFR 35 , Subpart $\mathrm{C}$ and are regarded an optional treatment used at the discretion of federal agencies for lead-based paint hazards identified in target housing constructed between 1960 and 1978 or conditions representing less than a lead-based paint hazard.

As a matter of policy, DoD also requires that lead-based paint hazards be abated in childoccupied facilities, soil-lead hazards surrounding housing constructed between 1960 and 1978, and soil-lead hazards remaining after target housing has been demolished and redeveloped for residential use. The abatement must be conducted within 12 months after completion of the risk assessment, and DoD prefers that abatement be made a condition of transfer, in which case the services must ensure that the transferee carries out the abatement prior to occupancy or sale. DoD policy also allows for either interim controls, no action, or abatement to be used to address potential soil-lead hazards (concentrations of lead in bare soil between 400 and $2000 \mathrm{ppm}$ (excluding children's play areas)), depending on the presence and likelihood of exposure to children. Situations in which the various control or hazard abatement measures apply, as determined by the regulations and DoD policy, are described in Table 3-1.

After lead-based paint control and hazard abatement measures have been completed, affected structures must undergo a clearance examination to ensure that all abatement activities have been conducted properly. Clearance examinations will usually be performed by the transferee since most control and hazard abatement activities will be carried out following transfer. In such cases, equirements for control, abatement, and clearance activities must be included in the contract for sale or transfer agreement.

In many cases, there are specific state and local regulations that must be considered in the design and implementation of any lead-based paint abatement or control activity. It is important to consult with state and local agencies before initiating any control or abatement actions. Figure 3-1 generally describes the lead-based paint control and hazard abatement process. 
Table 3-1. Situations Applicable to Lead-Based Paint Control and Hazard Abatement Measures

\begin{tabular}{|c|l|}
\hline $\begin{array}{c}\text { Control and Hazard } \\
\text { Abatement Measures }\end{array}$ & \multicolumn{1}{|c|}{ Potentially Applicable Situations } \\
\hline $\begin{array}{c}\text { No Further Action } \\
\text { (no hazards) }\end{array}$ & $\begin{array}{l}\text { Lead-based paint is not present. } \\
\text { Property is not target housing or intended to be } \\
\text { reused as a child-occupied facility*. } \\
\text { No lead-based paint hazards or potential soil-lead- } \\
\text { hazards are present. }\end{array}$ \\
\hline $\begin{array}{c}\text { Control Measures } \\
\text { (potential soil-lead hazards) }\end{array}$ & $\begin{array}{l}\text { In some circumstances, soil lead concentrations in } \\
\text { bare soils between } 400 \text { and } 2,000 \text { ppm (excluding } \\
\text { children's play areas) may be addressed through } \\
\text { control measures. This is established by the risk } \\
\text { assessment based on proximity to children's play } \\
\text { areas, extent of bare soils, state and local } \\
\text { requirements, and technical feasibility of any } \\
\text { control actions. }\end{array}$ \\
\hline Abatement \\
(lead-based paint hazards)
\end{tabular}

*Note: Target housing that will be demolished and reused for residential use after transfer will require the evaluation and control of soil-lead hazards. 


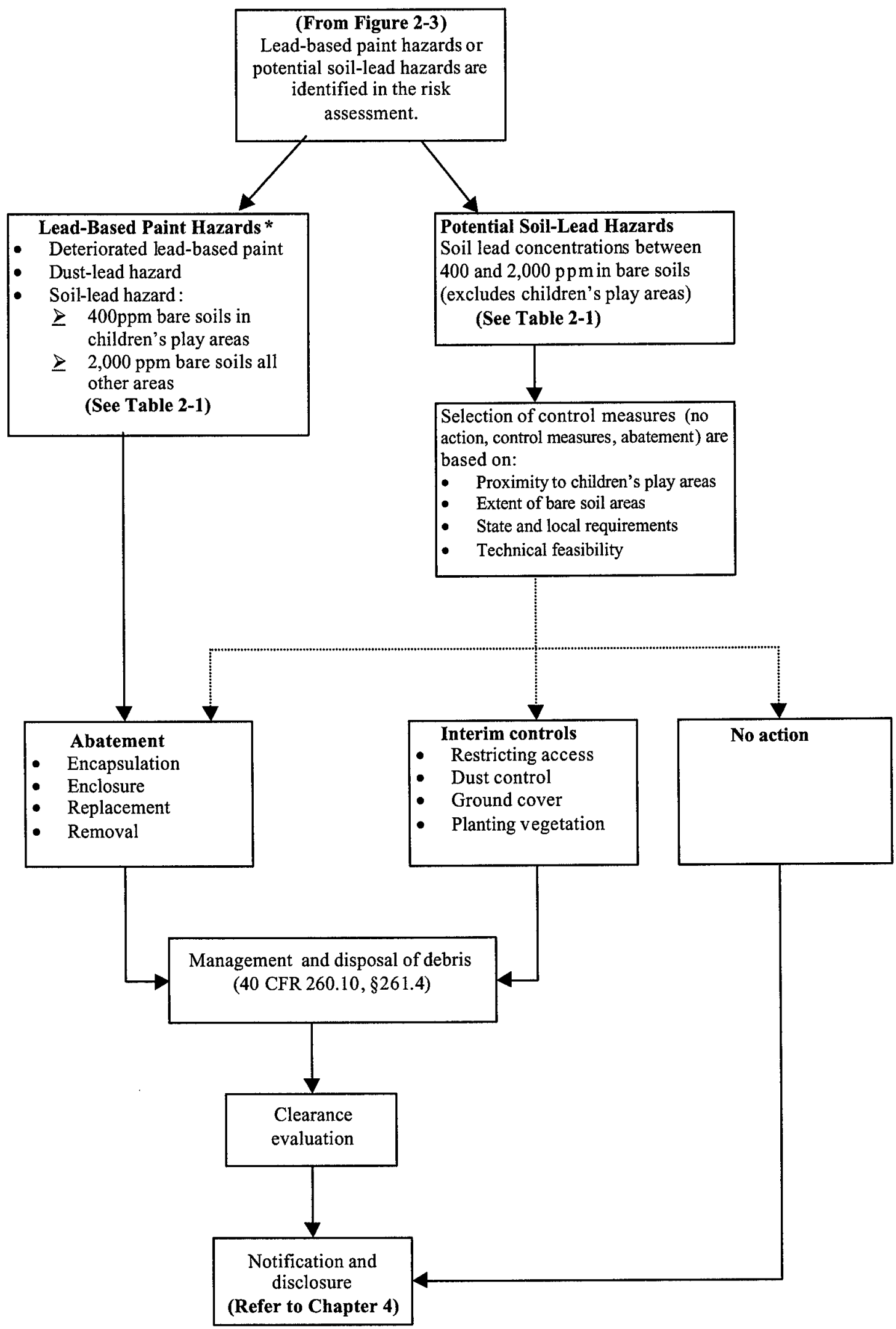

Figure 3-1. Control and Hazard Abatement Measures

*Only soil-lead hazards are required to be abated in target housing constructed between 1960-1978. 


\section{Control Measures}

Title $\mathrm{X}$ defines control measures [interim controls] as "a set of measures designed to reduce temporarily human exposure or likely exposure to lead-based paint hazards, including specialized cleaning, repairs, maintenance, painting, temporary containment, ongoing monitoring of lead-based paint hazards or potential hazards, and the establishment and operation of management and resident education programs."

Control measures can be used to reduce or temporarily eliminate the potential for children to develop adverse health effects from exposure to potential soil-lead hazards. As discussed on page 17 and Table 3-1, control measures can be appropriate for bare soils with an average soil lead concentration between 400 and 2,000 ppm, not observed to be used as a children's play area. Risk factors to consider in selecting control measures would be the proximity and the extent of bare soils available for exposure by children in nearby play areas. Non-risk factors include promulgated state and local requirements, as well as the technical feasibility of implementing any control measures. Soil that is adequately covered with vegetation, paving, or other landscape material should not generally require either control or abatement actions. State and local authorities should be contacted to identify additional requirements that should be considered for control measures.

Control measures for potential soil-lead hazards can include planting grass or ground cover, mulch, or restricting access, and should be selected on the basis of both risk and non-risk factors. Types of control measures are listed in Box 3-1. The basic elements of control measures include planning, implementation of controls, cleanup, clearance, and any ongoing maintenance and monitoring required to be performed by the transferee. The lead-based paint hazard control plan, prepared by the risk assessor, should identify any feasible control options that may be implemented to address potential soil-lead hazards (HUD Guidelines, Chapter 11, http://www.hud.gov/lea/leach11.pdf).

Box 3-1: Soil-Lead Hazard Control Measures (EPA and HUD Guidelines)

- Planting ground cover or shrubbery to reduce exposure to bare soil

- Covering bare soil with mulch or vegetation

- Removing and controlling dust

- Restricting access through posting, fencing, or other actions 


\section{ABATEMENT}

Title $X$ defines abatement as any set of measures designed to permanently eliminate leadbased paint hazards. EPA and HUD consider permanent measures as those that last at least 20 years. Under this definition, abatement includes removal of lead-based paint and dust-lead hazards, enclosure or encapsulation of lead-based paint, replacement of lead-painted components or fixtures, removal or permanently covering of lead-contaminated soil, and all preparation, cleanup, disposal, and post-abatement clearance testing activities associated with such measures.

Abatement does not include renovation, remodeling, landscaping, or other activities when such activities are not designed to permanently eliminate lead-based paint hazards but instead are designed to repair, restore, or remodel a given structure or dwelling (40 CFR 745.223). Even though these activities may incidentally result in the reduction or elimination of lead-based paint hazards, they are not considered abatement. Abatement also does not include control measures, operation and maintenance activities, and other measures designed to temporarily reduce leadbased paint hazards.

Chapter 12 of the HUD Guidelines describes the general principles of abatement such as building component replacement, enclosure systems, paint removal, and soil abatement (http://www.hud.gov/lea/leach12.pdf). Encapsulation is discussed in Chapter 13 of the HUD Guidelines (tttp://www.hud.gov/lea/leach13.pdf). Some commonly used abatement strategies are listed in Box 3-2.

Prohibited lead-based paint abatement methods (40 CFR 745.227(e)(6)) include:

- Open flame burning or torching of lead-based paint.

- Machine sanding or grinding or abrasive blasting or sandblasting without HighEfficiency Particulate Air (HEPA) exhaust control

- Dry scraping (except in conjunction with heat guns or within 1.0 foot of electrical outlets or when treating defective paint spots totaling no more than 2 square feet in any one interior room or 20 square feet on exterior surfaces).

- Operating a heat gun at temperatures above 1,100 degrees Fahrenheit.

24 CFR 35, Subpart $C$ requires that abatement be conducted within 12 months of completion of the risk assessment. All abatement contractors and firms must be certified to perform abatement work, and all abatement workers must be trained and certified, in accordance with 40 CFR Part 745, Subpart L. Abatement activities are required to be recorded, and any monitoring or maintenance activities must be documented and disclosed to the purchaser of the housing. In addition, the location of enclosed or encapsulated lead-based paint may be required to be filed with the appropriate municipal agency for future reference when construction permits for renovation are issued. 
Box 3-2: Abatement Strategies for Lead-Based Paint Hazards

- Removal of lead-based paint

- Enclosure of lead-based paint

- Encapsulation of lead-based paint

- Replacement of building components that have lead-based paint

- Removal of lead-contaminated dust hazards

- Removal or covering of bare soil areas greater than 9 square feet with lead concentrations greater than or equal to 2,000 ppm or bare soils in children's play areas with lead concentrations greater than or equal to 400 ppm, with a durable cover such as pavement or concrete (not grass or sod)

\section{DisPosal}

Building debris and wastes from lead-based paint abatement activities may result in the generation of hazardous wastes. Transferees conducting these activities will be responsible for complying with all applicable disposal requirements. Transferees, Federal facilities (if applicable), and the contractors involved in abatement or control actions may be considered waste generators and must comply with the existing regulations outlined in RCRA, Subtitles C and D. Facilities should also identify any state and local regulations applicable to the treatment, storage, and disposal of lead-based paint abatement wastes.

Currently, RCRA requires that wastes from abatement and control activities be tested to determine whether the material is a characteristic waste requiring special handling and disposal requirements as a hazardous waste. If the individual or entity responsible for abatement (generator) produces more than $100 \mathrm{~kg}$ of hazardous waste per month, the generator must comply with the RCRA hazardous waste regulations. Hazardous wastes staged on site during abatement activities may be stored either until abatement work is completed or until sufficient waste has been collected to constitute a load or shipment; however, storage (particularly storage over 90 days for which a storage permit is required) and disposal must be managed in accordance with RCRA regulations.

If hazardous waste from a single generator is produced in small quantities (less than 100 $\mathrm{kg}$ of hazardous waste per month), it could be excluded as "conditionally exempt" through a small-quantity-generator exemption under 40 CFR $\$ 261.4$. Nonhazardous or exempt wastes may be managed as solid waste with disposal in a state-licensed or state-permitted solid waste facility. HUD has specific recommendations (HUD Guidelines, Chapter 10, "Hazardous and Nonhazardous Waste") for transport of nonhazardous architectural components. These include wrapping and sealing components in plastic during transport and securing waste containers. Exempted wastes should not be burned in a municipal solid waste incinerator, recycled to produce mulch, or reused unless all lead-based paint has been removed. 


\section{Chapter 4: \\ Property Transfer Process}

Title X has specific provisions for lead-based paint in federally owned target housing that is transferred. The federal agency may conduct the required control or abatement measures prior to transfer or the responsibility may be assumed by the transferee. In either case, any abatement or control measures required must be conducted no later than 12 months after the completion of the risk assessment. DoD prefers that in most cases responsibility for control or abatement be transferred to the purchaser, in which case the service must ensure that abatement is conducted in accordance with Title $\mathrm{X}$ (through contract clauses or self-certification by the transferee). Occupancy by the transferee is prohibited until all lead-based paint hazards are abated.

Responsibility for any long-term monitoring, periodic inspection, and reevaluation of the control measures and abatement required to be performed after transfer should be made a condition of sale.

Documentation requirements associated with each of these options include:

- Disclosing known lead-based paint and/or lead-based paint hazards

- Incorporating the results of the paint inspection and risk assessment into the Environmental Baseline Survey (EBS).

- Referencing disclosure and evaluation results in the Findings of Suitability to Transfer (FOSTs) and the deed or contract for sale.

\section{DisClOSURE}

Several disclosure requirements must be satisfied before a property containing lead-based paint or lead-based paint hazards can be transferred. The services must provide the purchaser/transferee with a lead hazard information pamphlet approved by EPA for this purpose. The EPA-approved pamphlet currently is "Protect Your Family from Lead in Your Home" (EPA 747-K-94-001). In addition, the services must disclose to the transferee the presence of any known lead-based paint and/or lead-based paint hazards and provide any available lead hazard evaluation reports. Transferees then have 10 days to conduct a risk assessment or an inspection to identify the presence of lead-based paint and/or lead-based paint hazards, before becoming obligated under the contract. If both parties concur, the requirement may be shortened, extended, or waived. The following information must be provided in an attachment to the contract for sale/transfer agreement ( 40 CFR $\$ 745.113$ and 24 CFR $\S 35.13$ ):

- A "Lead Warning Statement" describing the possibility that the property may present a risk of childhood lead poisoning (Title X specifies the exact wording of this statement).

- A statement signed by the transferee that the transferee has read and understood the lead hazard information pamphlet and acknowledges that he or she had a 10-day opportunity before transfer to conduct a risk assessment or a paint inspection. 
- A list of any records or reports available to the services pertaining to lead-based paint and/or lead-based paint hazards in the housing that have been provided to the transferee. If no such records or reports are available the service will indicate this in the attachment to the contract for sale/transfer agreement.

- A statement by transferee acknowledging the receipt of available reports and records.

- A statement by the transferee that he or she has had an opportunity to conduct a risk assessment or inspection or waived the opportunity.

- The signatures of the service representative and the transferee certifying the accuracy of their statements, to the best of their knowledge, along with the dates of the signatures.

For transfers carried out by property transfer agents, such as GSA, 24 CFR 35, Subpart A requires services to disclose to the agent the presence of any known lead-based paint and/or leadbased paint hazards in the target housing being transferred and the existence of any available records or reports pertaining to lead-based paint and/or lead-based paint hazards. In the attachment to the contract or transfer agreement, services are also required to include a statement that the agent has informed the services of their obligations under 42 U.S.C. $4852 \mathrm{~d}$, that the agent is aware of his/her duty to ensure compliance with the requirements of 24 CFR 35, Subpart $\mathrm{A}$, and the signatures of the service representative, agents, and the transferee certifying the accuracy of their statements.

Additional information on disclosure requirements, including an EPA lead hazard information pamphlet, can be obtained from the National Lead Information Center (1-800-424LEAD), from the EPA Lead Programs Internet home page at www.epa.gov/opptintr/lead/index.html, or the HUD Office of Hazard Control home page at http://www.hud.gov/lea.

\section{OTHER DOCUMENTATION REQUIREMENTS}

Reports of lead-based paint inspections and risk assessments prepared for the services by the certified inspectors and risk assessors should be incorporated into the facility Environmental Baseline Survey (EBS). ${ }^{5}$ These sections of the EBS shall be referenced in the transfer agreement and referred to in the Invitation for Bids issued for public sale of the property. The control action and abatement reports, which identify components that have been abated and/or treated and the clearance results, shall be included with the transfer documents as part of the disclosure records. The location of enclosed or encapsulated lead-based paint may be required to be filed with the appropriate municipal agency for future reference when construction permits for renovation are issued.

The FOST developed by the services should reference the EBS report and the disclosure information for the property. The transfer agreement or contract for sale should include disclosure statements and the agreements by which the transferee shall conduct any improvements or abatement of lead-based paint hazards, as well as any monitoring, periodic inspections, and other activities required for compliance with Title $\mathrm{X}$ for occupancy and future transfer of the property.

\footnotetext{
${ }^{5}$ An EBS documents the environmental condition of real and excess DoD property available for transfer to the community.
} 


\section{Box 4-1: Service Disclosure Requirements}

\section{Purchaser/transferee:}

- Disclose known lead-based paint and/or lead-based paint hazards

- Provide any lead-based paint inspection and risk assessment reports

- Provide transferee a lead hazard information pamphlet

- Allow 10 days for purchaser to conduct an assessment or inspection for the presence of lead-based paint and/or lead-based paint hazards

- Attach the following to the contract:

- "lead warning statement".

- a statement disclosing the presence of known lead-based paint and/or leadbased paint hazards

- a list of records or reports that have been provided to the transferee

- a statement by the transferee affirming receipt of the information and reports in the property deed

- a statement by the transferee that he/she has received an opportunity to conduct an inspection or risk assessment

- the signatures of DoD and the transferee attesting to the accuracy of their statements.

\section{Property transfer agents:}

- Disclose known lead-based paint and/or leadbased paint hazards

- Existence of available records or reports

- Attach the following to the contract:

- A statement that the agent has informed DoD of DoD's obligations under 42 U.S.C. 4852d

- The agent is aware of his/her duty to ensure compliance with the requirements of 24 CFR 35, Subpart A

- The signatures of DoD, agents, and the transferee certifying the accuracy of their statements 
Appendices 


\section{Appendix A \\ Glossary}

Unless otherwise specified, definitions in this appendix are derived from Title X, the Residential Lead-Based Paint Hazard Reduction Act.

Abatement: Any set of measures designed to permanently eliminate lead-based paint hazards in accordance with standards established by appropriate federal agencies. Such measures may include (1) removal of lead-based paint and lead-contaminated dust, permanent enclosure or encapsulation of lead-based paint, replacement of lead-based painted components or fixtures, and/or removal or covering of lead-contaminated soil and (2) all preparation, cleanup, disposal, and post-abatement clearance testing activities associated with such measures.

Accessible (chewable) surface: An interior or exterior surface painted with lead-based paint that is accessible to a young child to mouth or chew. A chewable surface is the same as an "accessible surface" as defined in 42 U.S.C. 4851 b(2). Hard metal substrates and other materials that cannot be dented by the bite of a young child are not considered chewable.

Agent: An agent is any party who enters into a contract with a seller or lessor, including any party who enters into a contract with a representative of the seller or lessor, for the purpose of selling or leasing target housing. This term does not apply to purchasers or any purchaser's representative who receives all compensation from the purchaser.

Arithmetic mean: The algebraic sum of data values divided by the number of data values (e.g., the sum of the concentration of lead in several soil samples divided by the number of samples. For soils, the arithmetic mean is the average of the composite samples. The composite concentrations are summed and divided by the number of composite samples included in the average. To evaluate soil-lead hazards composite samples from the midyard and dripline are used to derive an arithmetic mean of the yardwide average lead concentration.

Bare soil: Soil not covered by grass, sod, or other live ground covers, or by wood chips, gravel, artificial turf, or similar covering. Bare soil includes sand.

Certified: Licensed or certified to perform such activities as risk assessment, lead-based paint inspection, or abatement supervision, by either EPA or a State or Indian tribe with a lead-based paint certification program authorized by the Environmental Protection Agency (EPA), in accordance with 40 CFR 745.226.

Clearance examination: An activity conducted following lead-based paint hazard reduction activities to determine that the hazard reduction activities are complete and that no soil-lead hazards or settled dust-lead hazards exist in the dwelling unit or worksite. The clearance process includes a visual assessment and collection and analysis of environmental samples. 
Child-occupied facility: A building, or portion of a building, constructed prior to 1978, visited regularly by the same child, less than 6 years of age, on at least two different days within any week (Sunday through Saturday), provided that each day's visit lasts at least 3 hours, that the combined weekly visits last at least 6 hours, and that the combined annual visits last at least 60 hours. Child-occupied facilities may include, but are not limited to, day-care centers, preschools, and kindergarten classrooms (40 CFR Part 745.223).

Common Areas: A portion of a building that is generally accessible to all occupants. Such an area may include, but is not limited to, hallways, stairways, laundry and recreational rooms, playgrounds, community centers, garages, and boundary fences.

Component: An element of a dwelling unit or common area identified by type and location Examples include, but are not limited to, a bedroom wall, an exterior window sill, a baseboard in a living room, a kitchen floor, an interior window sill in a bathroom, a porch floor, stair treads in a common stairwell, or an exterior wall.

Composite sample. A collection of more than two subsamples of the same medium (e.g., dust, soil, or paint) from the same type of surface (e.g., floor, window sill, or window trough), not to exceed 10 subsamples, such that multiple samples can be analyzed as a single sample.

Control Measures [Interim controls]: A set of measures designed to reduce temporarily human exposure or the likelihood of exposure to lead-based paint hazards, including specialized cleaning, repairs, maintenance, painting, temporary containment, ongoing monitoring of leadbased paint hazards or potential soil lead hazards, and the establishment and operation of management and resident education programs.

Deteriorated paint: Any interior or exterior paint or other coating that is peeling, chipping, chalking, or cracking or any paint or coating located on an interior or exterior surface or fixture that is otherwise damaged or separated from the substrate.

Dust-lead hazard: Depending on the evaluation method used, a dust-lead hazard is surface dust that contains dust-lead loading at or exceeding the following:

\begin{tabular}{|l|c|c|c|}
\hline Evaluation Method & \multicolumn{3}{|c|}{ Surface $\left(\mathrm{ug} / \mathrm{ft}^{2}\right)$} \\
\hline Lead hazard screen & Floors & Interior window sills & Window troughs \\
N/A \\
Risk Assessment & 40 & 125 & N/A \\
Reevaluation & 40 & 250 & N/A \\
Clearance & 40 & 250 & 800 \\
\hline
\end{tabular}

Note: Floors include carpeted and uncarpeted interior floors. 
Dwelling unit: A single-family dwelling, including attached structures such as porches and stoops; or a housing unit in a structure that contains more than one separate housing units, and in which each such unit is used or occupied, or intended to be used or occupied, in whole or in part, as the home or separate living quarters of one or more persons.

Evaluation: A risk assessment, a lead hazard screen, a lead-based paint inspection, paint testing, or a combination of these to determine the presence of lead-based paint hazards or lead-based paint.

Expected to reside: There is actual knowledge that a child will reside in a dwelling unit reserved for the elderly or designated exclusively for persons with disabilities. If a resident is a woman known to be pregnant, there is actual knowledge that a child will reside in the dwelling unit.

Federally owned housing: Residential dwellings owned or managed by a federal agency, or for which a federal agency is a trustee or conservator.

Friction surface: An interior or exterior surface that is subject to damage by abrasion or friction, including, but not limited to, certain window, floor, and stair surfaces.

Impact surface: An interior or exterior surface that is subject to damage by repeated sudden force, such as certain parts of door frames.

Inspection: see [Paint] Inspection

Interim controls [Control Measures]: A set of measures designed to reduce temporarily human exposure or the likelihood of exposure to lead-based paint hazards, including specialized cleaning, repairs, maintenance, painting, temporary containment, ongoing monitoring of leadbased paint hazards or potential soil lead hazards, and the establishment and operation of management and resident education programs.

Lead-based paint: Paint or other surface coatings that contains lead in excess of $1.0 \mathrm{mg} / \mathrm{cm}^{2}$ of lead or more than 0.5 percent lead by weight.

Lead-based paint evaluation: A risk assessment, a lead hazard screen, a lead-based paint inspection, paint testing, or a combination of these to determine the presence of lead-based paint hazards or lead-based paint. (See Evaluation).

Lead-based paint hazard: Any condition that causes exposure to lead from lead-contaminated dust, lead-contaminated soil, or lead-contaminated paint that is deteriorated or is present in accessible surfaces, friction surfaces, or impact surfaces that would result in adverse human health effects, as established by the appropriate federal agency.

Lead hazard screen: A limited risk assessment activity that involves paint testing and dust sampling as described in 40 CFR 745.227(c). 
Multi-family property. Residential real property containing five or more dwelling units.

[Lead-based paint] Inspection: A surface-by-surface investigation to determine the presence of lead-based paint and the provision of a report explaining the results of the investigation.

Play area: An area of frequent soil contact by children of less than 6 years of age, as indicated by the presence of play equipment (e.g. sandboxes, swing sets, sliding boards, etc.) or toys or other children's possessions, observations of play patterns, or information provided by parents, residents, residents or property owners.

Random sampling: Samples collected from dwelling units and common areas selected at random from a multi-dwelling project, used to represent sample results for all dwelling units and common areas.

Reduction: Measures designed to reduce or eliminate human exposure to lead-based paint hazards through methods including interim controls and abatement.

Residential dwelling: (1) A single-family dwelling, including attached structures such as porches and stoops, or (2) a single-family dwelling unit in a structure that contains more than one separate residential dwelling unit and in which each such unit is used or occupied, or intended to be used or occupied, in whole or in part, as the home or residence of one or more persons.

Residential real property. Real property on which there is situated one or more residential dwellings used or occupied, or intended to be used or occupied, in whole or in part, as the home or residence of one or more persons. For the purposes of this guide, child-occupied facilities are included in this definition.

Risk assessment: An on-site investigation to determine and report the existence, nature, severity, and location of lead-based paint hazards in residential dwellings, including (1) information gathered regarding the age and history of the housing and occupancy by children under age 6; (2) visual inspection; (3) limited wipe sampling or other environmental sampling techniques; (4) other activity as may be appropriate; and (5) provision of a report explaining the results of the investigation.

Single room occupancy: Housing consisting of zero-bedroom dwelling units that may contain food preparation or sanitary facilities or both (see Zero-bedroom dwelling).

Soil-lead hazard: Bare soil on residential real property that contains lead from lead-based paint equal to or exceeding $400 \mathrm{ppm}$ in children's play areas, or equal to or exceeding $2000 \mathrm{ppm}$ in other areas with bare soils that total more than 9 square feet per residential property.

Target housing: Any housing constructed before 1978, except housing designated exclusively for the elderly or persons with disabilities (unless a child younger than 6 years of age also resides, or is expected to reside, in such housing) and except any zero-bedroom dwelling. 
Targeted sampling: Sampling that selects dwellings that are most likely to contain lead-based paint hazards to represent the other dwellings in a project or property based on information supplied by the owner (HUD Guidelines, Chapter 5).

Worst-case sampling: Sampling requiring a walk-through survey of all dwellings by the risk assessor in order to select the highest-risk dwellings based on direct visual evidence (HUD Guidelines, Chapter 5).

Zero-bedroom dwelling: Any residential dwelling in which the living areas are not separated from the sleeping area. The term includes efficiencies, studio apartments, dormitory or single room occupancy housing, military barracks, and rentals of individual rooms in residential dwellings (see Single room occupancy (SRO)). 


\section{Appendix B \\ References}

Air Force Base Conversion Agency. Interim Operating Procedures for Management of LeadBased Paint at BRAC Installations. August 16, 1996.

Alliance to End Childhood Lead Poisoning. EPA's National Guidelines for Lead Hazards in Dust, Soil, and Paint: A Summary and Analysis. August 1994.

Department of Defense Interagency Lead-Based Paint Task Force. Lead: A Quick Reference Guide for the Industrial Hygienist. April 1995.

Disclosure of Known Lead-Based Paint and/or Lead-Based Paint Hazards Upon Sale or Lease of Residential Property. 40 CFR 745, Subpart F and 24 CFR 35, Subpart A.

Housing and Community Development Act of 1992. Public Law 102-550. October 1992, Title X, Residential Lead-Based Paint Hazard Reduction Act of 1992, amended by the Toxic Substances Control Act.

Identification of and Listing of Hazardous Waste. 40 CFR 261 and Appendices.

Lead-Based Paint Activities. 40 CFR Part 745, Subpart L.

Notification to Purchasers and Tenants of HUD-Associated Housing Constructed Prior to 1978 of the Hazards of Lead-Based Paint Poisoning. 24 CFR 35, Subpart A.

Requirements for Hazard Education Before Renovation of Target Housing. 40 CFR Part 745, Subpart E.

Requirements for Notification, Evaluation, and Reduction of Lead-Based Paint Hazards in Federally Owned Residential Property and Housing Receiving Federal Assistance. 24 CFR 35 et al., 64 FR 50140, 15 September 1999.

Requirements for Lead-Based Paint Activities in Target Housing and Child-Occupied Facilities; Certification Requirements and Work Practice Standards for Individuals and Firms. 40 CFR Part 745, Subpart L; Amendment. Final Rule. 64 FR 42849, August 6, 1999.

Department of Defense, Acquisition and Technology. Responsibility for Additional Environmental Cleanup After Transfer of Real Property. 25 July 1997.

U.S. Army Center for Public Works. Installation Lead Hazard Management. Public Works Technical Bulletin (420-70-2). February 1997. 
U.S. Department of Housing and Urban Development, Office of Lead Hazard Control. Guidelines for the Evaluation and Control of Lead-Based Paint Hazards in Housing. June 1995. (Chapter 7 revised 1997).

U.S. Department of Housing and Urban Development. Lead Paint Safety, A Field Guide for Painting, Home Maintenance, and Renovation Work. June 1999.

U. S. Environmental Protection Agency. Identification of Dangerous Levels of Lead. Proposed Rule. 63 FR 30302, June 3, 1998.

U. S. Environmental Protection Agency. Temporary Suspension of Toxicity Characteristic Rule for Specified Lead-Based Paint Debris. Proposed Rule. 63 FR 70233, December 18, 1998.

U. S. Environmental Protection Agency. Management and Disposal of Lead-Based Paint Debris. Proposed Rule. 63 FR 70189, December 18, 1998.

U.S. Environmental Protection Agency. "Clarification to the 1994 Revised Interim Soil Lead Guidance for CERCLA Sites and RCRA Corrective Action Facilities." Office of Solid Waste and Emergency Response. Directive 9200.4-27P, August 27, 1998.

U.S. Environmental Protection Agency, Office of Pollution Prevention and Toxics. Guidance on Residential Lead-Based Paint, Lead-Contaminated Dust, and Lead-Contaminated Soil. 60 FR 47248, 11 September 1995. 


\section{Appendix C \\ Lead Based Paint Standards and Test Methods}

\section{ASTM Standards}

\section{$\underline{\text { Sampling and Analysis }}$}

1. Dust

- E 1728, Standard Practice for Field Collection of Settled Dust Samples Using Wipe Sampling Methods for Lead Determination by Atomic Spectrometry Techniques.

- E 1973, Provisional Standard Practice for the Collection of Surface Dust by Air Sampling Pump Vacuum Technique for Subsequent Lead Determination.

- E 1792, Standard Specification for Wipe Sampling Materials for Lead in Surface Dust.

- E 1644, Standard Practice for Hot Plate Digestion of Dust Wipe Samples for the Determination of Lead by Atomic Spectrometry.

- PS 88, The Determination of Lead in Paint, Settled Dust, Soil and Air Particulate by Field-Portable Electroanalysis.

- E 1741, Standard Practice for Preparation of Airborne Particulate Lead Samples Collected During Abatement and Construction Activities for Subsequent Analysis by Atomic Spectrometry.

2. Soil

- E 1727, Standard Practice for Field Collection of Soil Samples for Lead Determination by Atomic Spectrometry Techniques.

- E 1726, Standard Practice for Sample Digestion of Soils for the Determination of Lead by Atomic Spectrometry.

- PS 88, The Determination of Lead in Paint, Settled Dust, Soil and Air Particulate by Field-Portable Electroanalysis.

3. Paint

- E 1729, Standard Practice for Field Collection of Dried Paint Samples for Lead Determination by Atomic Spectrometry Techniques.

- E 1645, Standard Practice for the Preparation of Dried Paint Samples for Subsequent Lead Analysis by Atomic Spectrometry. 
- E 1753, Use of Qualitative Chemical Spot Test Kits for Detection of Lead in Dry Paint Films.

- PS 88, The Determination of Lead in Paint, Settled Dust, Soil and Air Particulate by Field-Portable Electroanalysis.

- PS 95, Provisional practice for quality systems for conducting in situ measurements of lead content in paint or other coatings using field-portable x-ray fluorescence XRF devices.

- E 1775, Standard Guide for Evaluating Performance of On-Site Extraction and FieldPortable Electrochemical for Spectrophotometric Analysis of Lead.

- E 1613, Standard Test Method for Analysis of Digested Samples for Lead by Inductively Coupled Plasma Atomic Emission Spectrometry (ICP-AES), Flame Atomic Absorption (FAAS), or Graphite Furnace Atomic Absorption (GFAAS) Techniques.

- E 1828, Evaluating the Performance Characteristics of Qualitative Chemical Spot Test Kits for Lead in Paint.

\section{$\underline{\text { Lead-Based Paint Management and Abatement }}$}

1. Management

- E 1864, Practice for Evaluating Quality Systems of Organizations Engaged in Conducting Facility and Hazard Assessments to Determine the Presence and Extent of Lead in Paint, Dust, Airborne Particulate, and Soil.

- E 1908, Standard Guide for Sample Selection of Debris Waste from a Building Renovation or Lead Abatement Project for Toxicity Characteristic Leaching Procedure (TCLP) Testing for Leachable Lead.

- E 1605, Standard Terminology Relating to Abatement of Hazards from Lead-Based Paint in Buildings and Related Structures.

- PS 53, Provisional Standard Guide for Identification and Management of Lead Hazards in Facilities.

2. Abatement

- E 1795, Standard Specification for Non-Reinforced Liquid Coating Encapsulation Products for Leaded Paint in Buildings.

- E 1796, Standard Guide for the Selection and Use of Liquid Coating Encapsulation Products for Leaded Paint in Buildings. 
- E 1797, Standard Specification for Reinforced Liquid Coating Encapsulation Products for Leaded Paint in Buildings.

\section{Other Applicable Standards}

\section{Lead Hazard Sampling Protocols and Strategies}

"Residential Sampling for Lead: Protocols for Dust and Soil Sampling," Environmental Protection Agency, EPA 747-R-95-001, March 1995. (Note: The protocols presented in this document are equivalent to ASTM methods.)

"Guidelines for the Evaluation and Control of Lead-Based Paint Hazards in Housing," Department of Housing and Urban Development, June 1995, Revised Chapter 7, September 1997.

40 CFR Part 745, "Lead-Based Paint Activities."

EPA Memorandum, "Guidance on Residential Lead-Based Paint, Lead-Contaminated Dust, and Lead-Contaminated Soil, 11 September 1995, 60 FR 47248.

Analysis Methods

U.S. Environmental Protection Agency. "Test Methods for Evaluating Solid Waste Physical/Chemical Methods," EPA SW 846. Specific methods include:

- 3050, Dust Wipe Digestion

- 7420, 7421, 6010, Atomic Absorption or Inductively Coupled Plasma Atomic Emission Spectrometry

"National Institute for Occupational Safety and Health Manual of Analytical Methods." Methods include:

- 7082, Atomic Absorption (AA) Flame

- 7105, AA Graphite Furnace

- 7300, Elements ICP

- 7701, Ultrasound/Anodic Stripping Voltammetry

- 9100, Lead in Surface Wipe Samples

ID 125G, "Metals and Metaloid Particulates," OSHA Analytical Methods. (inductively coupled plasma atomic emission spectrometry [ICP-AES] method.) 


\section{Appendix D}

\section{Questions \& Answers}

\section{Are a lead-based paint inspection and a risk assessment required for all pre-1978 housing prior to transfer?}

Yes, unless an inspection finds that the property is free of lead-based paint. Title $\mathrm{X}$ requires inspection and abatement of lead-based paint hazards in housing constructed prior to 1960 , and an inspection for lead-based paint and lead-based paint hazards in target housing constructed between 1960 and 1977. 24 CFR 35, Subpart C clarifies these provisions, requiring a leadbased paint evaluation (an inspection, risk assessment, or combination of thereof) be performed for all pre-1978 target housing prior to transfer. The risk assessment must be performed within 12 months of transfer, and abatement must be conducted within 12 months of completion of the risk assessment.

2. What is a lead-based paint hazard in regard to friction, impact, or accessible surfaces, and what is required to be abated?

As stated in section 1013 of Title X, a lead-based paint hazard is "any condition that causes exposure to lead from lead-contaminated dust, lead-contaminated soil, or lead-contaminated paint that is deteriorated or present in accessible surfaces, friction surfaces, or impact surfaces that would result in adverse human health effects..." As described in Table 2-1 in this guide, and 24 CFR 35, Subpart R, impact surfaces require treatment (i.e., abatement or interim controls) only if all of the following conditions are met: (1) the surface is damaged or has otherwise deteriorated, (2) the damaged paint is caused by impact from a related building component, (3) the surface contains lead-based paint. Friction surfaces require treatment only if all of the following conditions are met: (1) a dust lead hazard is present on the nearest horizontal surface underneath the friction surface, (2) paint on the surface is abraded or deteriorated, and (3) the surface contains lead-based paint. Accessible surfaces require treatment only if there is evidence that a child has chewed or mouthed that surface.

\section{Is scraping and painting over deteriorated paint with 20-year paint adequate abatement?}

Lead-based paint abatement refers to a group of measures that can be expected to eliminate or reduce exposures to lead-based paint hazards for at least 20 years under normal conditions. If the "20-year paint" meets the qualifications of an encapsulant in Chapter 13 of the HUD Guidelines and it is applied in accordance with manufacturers instructions, it should be an acceptable treatment for deteriorated paint. 
4. What information should be included in the property transfer documents if the target housing is scheduled to be demolished and the property will not be reused for residential redevelopment?

Lead-based paint evaluation and abatement are not required if the housing is not reused for habitation. However, DoD policy requires the evaluation and abatement of soil-lead hazards in residential real property that will be demolished and redeveloped for residential purposes following transfer. Requirements for evaluation and abatement should be made a condition of the property transfer, in which case the transferee will be required to evaluate and abate any soillead hazards after demolition and prior to occupancy of any newly constructed housing units. The transfer agreement should reference Field Guide evaluation requirements and the soil-lead hazard criteria in Table 2-1.

5. Do we have to abate lead-based paint hazards in target housing prior to transfer? If the responsibility for abatement is transferred to the purchaser, what will the federal agency be required to do to fulfill requirements under Title $X$ ?

Under 24 CFR 35, Subpart C, the federal agency may conduct the required abatement prior to transfer or that responsibility may be assumed by the transferee. The federal agency is required to conduct a lead-based paint inspection and risk assessment prior to transfer, and the risk assessment must be performed no more than 12 months prior to transfer. Abatement must begin no more than 12 months after the completion of the risk assessment. Occupancy by the transferee is prohibited until all lead-based paint hazards are abated. DoD prefers that responsibility for abatement be transferred to the purchaser, in which case the service must ensure that abatement is conducted in accordance with Title X. Assurances that the purchaser will perform required abatement activities are provided through contractual mechanisms.

\section{When are interim controls appropriate and when are they inappropriate?}

Control measures or interim controls may be used as an optional treatment at the discretion of federal agencies to address hazards not required to be abated under 24 CFR 35, Subpart C and conditions representing less than a lead-based paint hazard. Control measures, along with abatement or no action, may be appropriate alternatives to address potential soil lead-based paint hazards (soil lead concentrations in bare soils between 400 and 2,000 ppm (excluding children's play areas) which are not considered to be lead-based paint hazards but are present in amounts or under conditions that may be a potential exposure hazard to children Selection of alternatives for potential soil lead hazards should be evaluated on the basis of the risk assessment and criteria contained in Chapter 2 of the Field Guide. 


\section{Appendix E}

\section{DoD Policy and EPA-DoD Agreements}




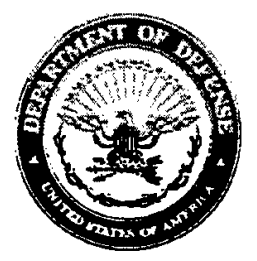

THE DEPARTMENT OF DEFENSE

AND

THE UNITED STATES

ENVIRONMENTAL PROTECTION AGENCY

WASHINGTON, DC $\uparrow 7 \mathrm{MAR}$

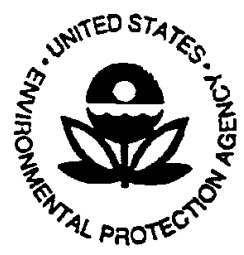

SUBJECT: Management of Lead-Based Paint in Residential and Non-Residential Areas at Base Realignment and Closure (BRAC) Properties

The purpose of this memorandum is to transmit the agreements (attached) EPA and DoD reached on August 14,1998, and to provide a schedule for completing the actions the agencies agreed to jointly undertake.

Residential Areas: EPA and DoD agreed that Title X (of the Housing and Community Development Act of 1992, 42 U.S.C. 4822) procedures provide an efficient, effective, and legally adequate framework for addressing lead-based paint in residential areas and that, as a matter of policy, CERCLA/RCRA will not be applied except in limited circumstances. DoD actions to address the threat of lead poisoning from lead-based paint in residential areas will be conducted in accordance with Title X/TSCA requirements. To assist EPA and DoD personnel to understand and comply with current HUD, EPA, and OSHA regulations on lead-based paint, EPA and DoD are jointly developing a guidance document entitled, Lead-Based Paint Guidelines for Disposal of Residential Property: A Field Guide. The target date for completing the Field Guide is May 28, 1999.

Non-Residential Areas: EPA will conduct and fund a national pilot study, with DoD coordination, to assess lead-based paint hazards in non-residential areas. The target date EPA and DoD have set for finalizing the pilot study is May 14, 1999. EPA and DoD agreed that sampling efforts on non-residential areas would be limited, pending the results of the pilot study to: 1) certain types of metallic structures (water towers, communications towers, and bridges) where soil-lead from lead-based paint is reasonably expected to exist, or 2) specific areas of the parcel or structure where the know'n future use is as a child occupied facility. After the results of the pilot study, the types of structures to be sampled will be re-assessed. EPA agreed not to require sampling of all non-residential areas for lead-based paint. EPA and DoD also agreed to develop model language on lead-based paint for the Finding of Suitability to Transfer (FOST) document for non-residential property. This model language will generally describe what has been done regarding lead-based paint hazards and DoD and transferee responsibilities. Final agreement on sampling for lead-based paint in non-residential areas will be included in the cover memorandum for the model FOST language.

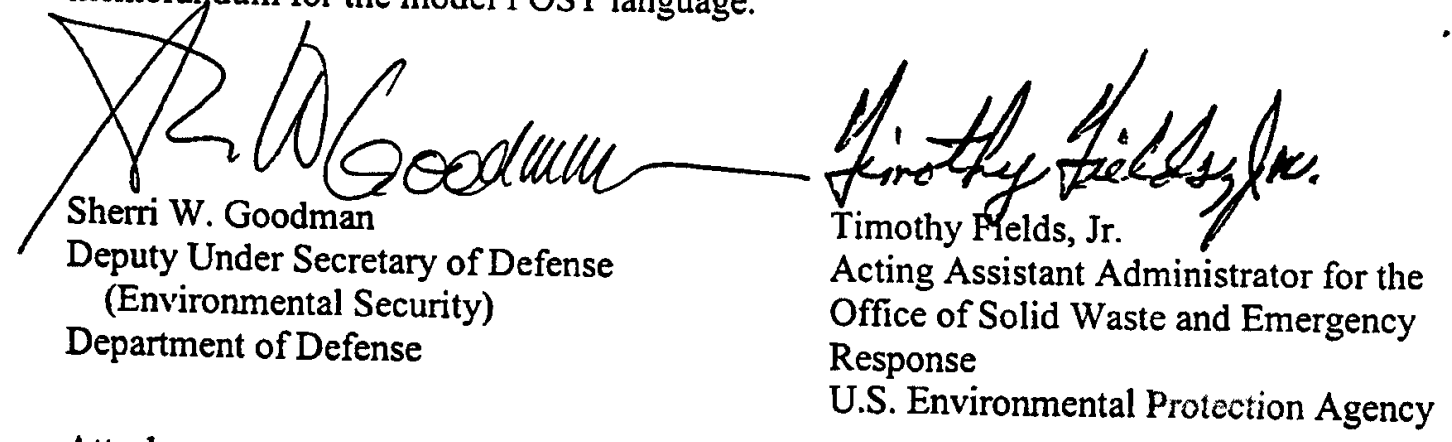

Attachment 


\section{SUMMARY OF EPADDD AUGUST $14^{\text {th }}$ MEETING}

The Environmental Protection Agency (EPA) and the Department of Defense (DoD) want to ensure that lead in soil from lead-based paint is addressed in a manner that: (1) is protective of human health and the environment, (2) is consistent with nationally applicable regulations and standards, and (3) supports the President's Five Point Plan for Base Realignment and Closure (BRAC) Property Reuse.

EPA and DoD discussed alternatives for addressing lead-based paint in both residential and nonresidential areas and the application of Title X (the Residential Lead-Based Paint Hazard Reduction Act) including section 403 of the Toxic Substances Control Act (TSCA), and the Comprehensive Environmental Response Compensation and Liability Act (CERCLA) for assessing lead-based paint hazards. EPA's key concern was whether actions taken under another statutory authority would be sufficient to provide the covenants required under section 120(h)(3) of CERCLA. DoD's key issue was that DoD not be regulated differently, and in this case more stringently, than any other federal agency or private entity.

Resolved for Residential Areas: EPA has concluded that release of lead-based paint to soil is a release of a hazardous substance under CERCLA, but that generally Title X/TSCA 403 is the appropriate regulatory regime for addressing lead-based paint hazards in residential areas in the majority of situations. It was agreed that Title $\mathrm{X}$ procedures, provide an efficient, effective, and legally adequate framework for addressing lead-based paint in residential areas and that, as a matter of policy, CERCLA/Resource Conservation and Recovery Act (RCRA) would not be applied except in limited circumstances. DoD stated that, although they are not legally required by Title $\mathrm{X}$ to do so, it is willing prospectively, as part of an overall resolution of the lead-based paint issue, to abate 1960-1978 target housing (as defined in Title X) with lead-based paint hazards where a risk is indicated, or to otherwise ensure that such structures will not be used as target housing until such abatement is performed by either DoD or the grantee. DoD and EPA agreed to jointly develop a field guide summarizing the Department of Housing and Urban Development's (HUD) Title X and EPA's TSCA 403 requirements and that the Field Guide will outline the limited circumstances under which CERCLA/RCRA would be used.

If DoD installations comply with jointly developed guidelines, EPA agreed it will review the Finding of Suitability to Transfer (FOST) without adverse comments regarding lead-based paint.

\section{Resolved for Non-Residential Areas:}

EPA will conduct and fund a national pilot program, with DoD coordination, to assess leadbased paint hazards in non-residential areas, provided this pilot also assesses non-DoD sites such as public, private, Superfund, RCRA, and Brownfields sites.

DoD and EPA also agreed to develop model FOST language. This model language will generally describe what has been done regarding lead-based paint hazards and DoD and transferee responsibilities. 
Further, EPA and DoD agreed that sampling efforts on non-residential areas would be limited, pending the results of the pilot program, to certain types of structures where high concentrations of lead-based paint are reasonably expected to exist. EPA agreed not to require sampling of all non-residential areas for lead-based paint. DoD agreed to provide EPA with a proposed list of structures for further consideration. Once agreed to, these structures will be assessed under the procedures of CERCLA and DoD's Defense Environmental Restoration Program (DERP). The type of structures DoD has proposed for such sampling are water towers, communication towers, and bridges. EPA believes that sampling or other requirements to be defined in the model FOST or in the Field Guide may be appropriate in the specific area of the parcel or structure where the known future use is as a child occupied facility.

The model FOST language and agreement on specific structures will enable DOD, EPA, and the states to focus resources on areas likely to pose the greatest risk.

\section{Other Agreements Reached:}

1. EPA and DoD will work together to communicate strategies on lead-based paint. EPA and DoD jointly developed a press release based on the agreements during the August 14 meeting. The press release was issued on August 21, 1998.

2. EPA will not issue a separate OSWER policy on lead-based paint for CERCLA section $120(\mathrm{~h})$ properties as long as progress is being made, and such a policy will only be issued in consultation with DoD.

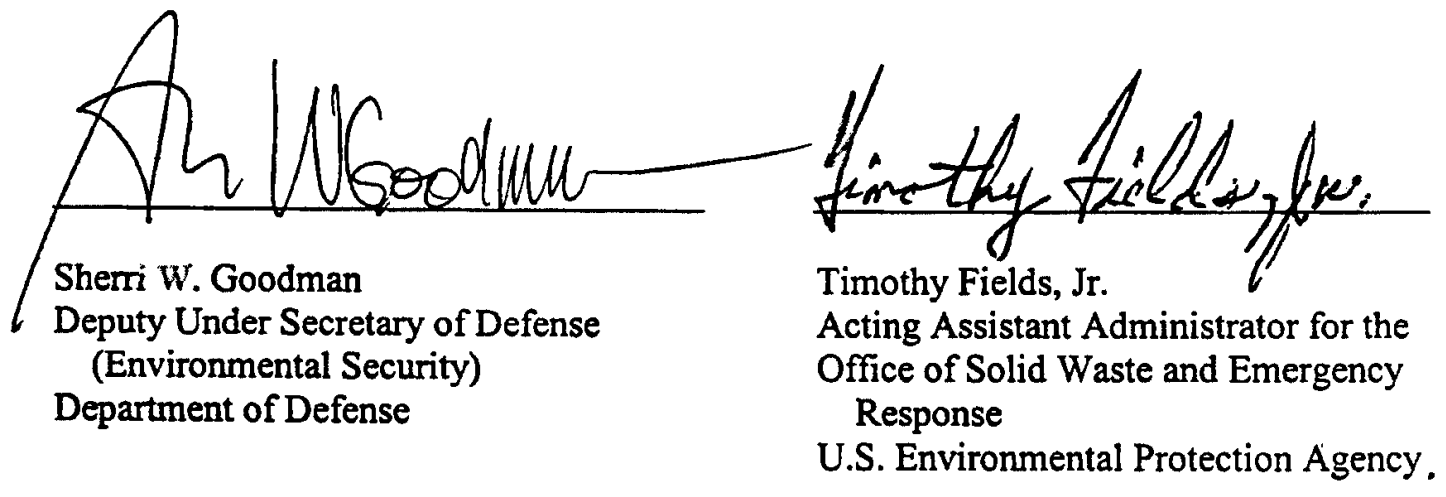




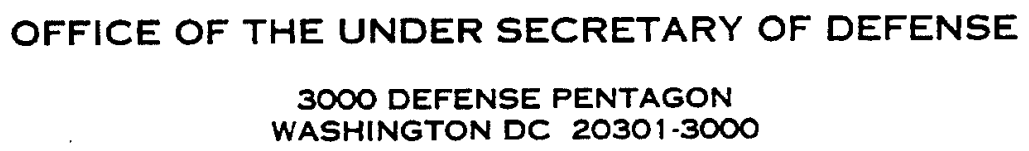

MEMORANDUM FOR ASSISTANT SECRETARY OF THE ARMY

\author{
(INSTALLATIONS, LOGISTICS, AND ENVIRONMENT) \\ ASSISTANT SECRETARY OF THE NAVY \\ (INSTALLATIONS AND ENVIRONMENT) \\ ASSISTANT SECRETARY OF THE AIR FORCE \\ (MANPOWER, RESERVE AFFAIRS, INSTALLATIONS \\ AND ENVIRONMENT) \\ DIRECTOR, DEFENSE LOGISTICS AGENCY
}

SUBJECT: Lead-Based Paint Policy for Disposal of Residential Real Property

The Department of Defense (DoD) policy is to manage lead-based paint in a manner protective of human health and the environment and to comply with all applicable Federal, State, or local laws regulating lead-based paint and lead-based paint hazards.

The attached Field Guide is a joint DoD and Environmental Protection Agency (EPA) guidance document for use by DoD and EPA personnel in the evaluation and control of lead-based paint at DoD residential real property scheduled for disposition under the base realignment and closure (BRAC) program. Lead-based paint requirements are defined by Title X, the Residential Lead-Based Paint Hazard Reduction Act of 1992, which amended the Lead-Based Paint Poisoning Prevention Act (42 U.S.C, Section 4822) and its implementing regulations (under the EPA Toxic Substances Control Act (TSCA) Section 403 rule and the Department of Housing and Urban Development (HUD) Section 1013 rule). DoD will issue separate policy on lead-based paint requirements for transferring non-residential properties.

The Field Guide provides a general roadmap summarizing the requirements for the evaluation and control of lead-based paint hazards in target housing as defined by Title $\mathrm{X}$ and TSCA. In addition to existing Title $\mathrm{X}$ requirements, the Field Guide also specifies some actions that exceed Title $X$ requirements. These actions represent DoD's desire to go beyond actions strictly required by law to ensure that activities taken in this regard are protective of human health and the environment. DoD policy is to:

- Abate soil-lead surrounding housing constructed between 1960 and 1978 (Title X requires abatement of lead-based paint hazards in target housing constructed prior to 1960). The transfer agreement may require the purchaser to perform the abatement activities.

- Evaluate the need for interim controls, abatement, or no action for bare soil lead concentrations between 400 and 2000 ppm (excluding children's play areas) based on the findings of the lead-based paint inspection, risk assessment, and criteria contained in the Field Guide. 
- Evaluate and abate lead-based paint hazards in structures reused as child-occupied facilities located on residential real property. Child-occupied facilities are day care centers, preschools, and kindergarten classrooms visited regularly by children under six years of age.

- Evaluate and abate soil-lead hazards for target housing demolished and redeveloped for residential use following transfer. Under Title $\mathrm{X}$, residential dwellings that are demolished or not intended for occupancy after transfer do not require an inspection and risk assessment or lead-based paint control and hazard abatement. However, DoD requires that the terms of property transfer include a requirement for the transferee to evaluate and abate any soil-lead hazards prior to occupancy of any newly constructed dwelling units.

By adding these additional measures as a matter of policy, DoD believes it exceeds measures necessary to reduce potential lead exposures in children and will significantly contribute to the elimination of adverse effects in children from exposures to lead from lead-based paint in federally-owned target housing subject to disposition.

This lead-based paint policy supersedes the DoD 31 October 1994 lead-based paint policy attached to the PADUSD (ES) memorandum, Asbestos, Lead Paint, and Radon Policies at BRAC Properties. The asbestos and radon policies referenced in the memorandum remain in effect. Property transfer agreements executed under the previous policy are not required to meet these requirements. The effective date implementing these requirements is 30 March 2000.

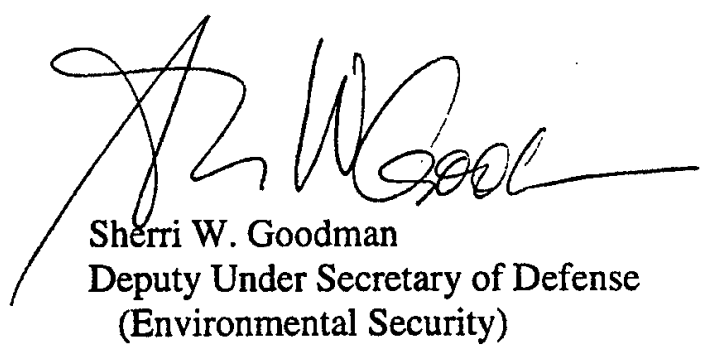

Attachment 


\section{INTERNET DOCUMENT INFORMATION FORM}

A . Report Title :Lead Based Guidelines for Disposal of Department of Defense Residential Real Property a Field Guide

Downloaded From the Internet 00 December 1999

C. Report's Point of Contact: (Name, Organization, Address, Office Symbol, \& Ph \# Air Command and Staff College Department of the Air Force Maxwell Air Force Base Alabama 36112-6424

D. Currently Applicable Classification Level: Unclassified

E. Distribution Statement A: Approved for Public Release

F. The foregoing information was compiled and provided by: DTIC-OCA, Initials:_JC___ Preparation Date: 2000/12/11

The foregoing information should exactly correspond to the Title, Report Number, and the Date on the accompanying report document. If there are mismatches, or other questions, contact the above OCA Representative for resolution. 